\title{
Töredékes égerligetek a Nyírségben (Paridi quadrifoliae-Alnetum glutinosae Kevey in Borhidi et Kevey 1996)
}

\author{
Kevey Balázs ${ }^{1} \&$ Papp LÁszló ${ }^{2}$ \\ ${ }^{1}$ Pécsi Tudományegyetem, Ökológiai Tanszék, H-7624 Pécs, Ifjúság u. 6. \\ e-mail: keveyb@gamma.ttk.pte.hu \\ 2Debreceni Egyetemi Botanikus kert, H-4032 Debrecen, Egyetem tér 1. \\ e-mail: papp.laszlo@gf.unideb.hu
}

KeveY, B. \& PAPP, L.: Fragmentary alder gallery forests in the Nyirség.

Abstract: During my vegetation research in the Nyírség, I collected vegetation samples of fragmentary alder dominated forests resembling alder gallery forests. In this paper, I present the results of my phytosociological analyses and describe the phytosociological characteristics of the studied stands using ten relevés. Because of their similarity to the association Paridi quadrifiliae-Alnetum glutinosae Kevey in Borhidi et Kevey 1996 described from the Szigetköz, and substantial difference from the Aegopodio-Alnetum Kárpáti V., Kárpáti I. et Jurko ex Šomšák 1961 distributed in the mountain ranges, they are identified with the former association.

Keywords: Syntaxonomy, alder gallery forests on sand, cluster analysis, ordinatio.

\section{Bevezetés}

Az Alnus glutinosa a Nyírségben többnyire ültetett formában található (Papp ined.). Ebből következik, hogy a természetszerü égerligetek is ritkák. Kutatásaink során mindössze három erdőben találtuk meg ezt az erdőtársulást, így a Terem melletti „Nagyfenék” nevü helyen, a Nyírábránynál levő „Mogyorósi-erdő”-ben, valamint Mérknél a „Vadaskerti-erdő”-ben. E három erdőből összesen tíz cönológiai felvételt sikerült készítenünk, s e felvételi anyag alapján jellemezzük a Nyírség töredékes égerligeteit.

\section{Anyag és módszer}

A cönológiai felvételeket a Zürich-Montpellier növénycönológiai iskola (BECKING 1957, BRAUN-BlanQUET 1964) hagyományos kvadrát-módszerével készítettük. A felvételek táblázatos összeállítását, valamint a karakterfajok csoportrészesedését és csoporttömegét az „NS” számítógépes programcsomag (KEVEY - HIRMANN 2002) segítségével végeztük. A felvételkészítés és a hagyományos statisztikai számítások módszerét KEvEY (2008) korábban részletesen közölte. A Nyírség égerligeteit összehasonlítottuk a Szigetközböl leírt Paridi quadrifoliae-Alnetum társulással (KEVEY 2008), a Börzsönyböl 
ismert Aegopodio-Alnetum társulással (NAGY 1997), valamint a Nyírség tölgy-kőris-szil ligeteivel (KeVEY et al. 2017). Az asszociációk összehasonlításánál a SYN-TAX 2000 programcsomag (PODANI 2001) segítségével bináris adatokon alapuló hierarchikus osztályozást, cluster-analízist (hasonlósági index: Baroni-Urbani-Buser; osztályozó módszer: teljes lánc) és szintén bináris alapú ordinációt (hasonlósági index: Baroni-UrbaniBuser; ordinációs módszer: főkoordináta-analízis) készítettünk. A fajok esetében KIRÁLY (2009), a társulásoknál pedig az újabb hazai nómenklatúrát (BoRHIDI - KEVEY 1996, KEVEY 2008, BorHIDI et al. 2012) követjük. A társulástani és a karakterfaj-statisztikai táblázatok felépítése az újabb eredményekkel (OBERDORFER 1992, MucINA et al. 1993; KeVey 2008, Borhidi et al. 2012) módosított Soó (1980) féle cönológiai rendszerre épül. A növények cönoszisztematikai besorolásánál is elsősorban Soó (1964, 1966, 1968, 1970, 1973, 1980) Synopsis-ára támaszkodtunk, de figyelembe vettük az újabb kutatási eredményeket is (vö. BorHidi 1993, 1995, Horváth F. et al. 1995, KeveY 2008).

\section{Eredmények}

A Nyírség égerligeteiböl 1994 és 2007 között 10 cönológiai felvételt készítettünk. Alább e felvételi anyag alapján adjuk meg a társulás jellemzését.

\section{Termőhelyi viszonyok}

A vizsgált égerligetek a Nyírség homokvidékén, 115-237 m tengerszint feletti magasságban találhatók. Az alapkőzetet savanyú homokos öntésföld képezi, amelyen kissé kotus öntés erdőtalaj alakult ki. A vizsgált állományok mikroklímája hüvös, párás, talajuk a félnedves-nedves vízgazdálkodási fokozatba sorolható. Ezen égerligetek (Paridi quadrifoliae-Alnetum glutinosae) általában a mélyebben fekvő magyar kőrises égerlápok (Fraxino pannonicae-Alnetum glutinosae) és a magasabb szinten kialakult tölgykőris-szil ligetek (Fraxino pannonicae-Ulmetum) között helyezkednek el (1. ábra).

\section{Fiziognómia}

A felső lombkoronaszint közepesen, vagy erösebben zárt, $65-80 \%$ borítást mutat, magassága pedig - az állomány korától függően - 20-25 méter. Az átlagos törzsátmérő ennek megfelelően 35 és $50 \mathrm{~cm}$ között változik. Egyetlen állandó (K V) és egyben tömeges (A-D 3-4) fája az Alnus glutinosa és a Fraxinus angustifolia. Ritkább elegyfái a következök: Betula pendula, Cerasus avium, Populus alba, Populus nigra, Populus tremula, Quercus robur, Tilia tomentosa, Ulmus minor. Az alsó lombkoronaszint általában gyengén, vagy közepesen fejlett. Borítása 20-40\%, magassága pedig 13-18 m. Állandó (K IV-V) fái az Alnus glutinosa és a Fraxinus angustifolia. Nagyobb tömeget mutató fa ebben a szintben nem található. E szintet elérheti a fává nőtt Corylus avellana és a Hedera helix (1-2. táblázat). 


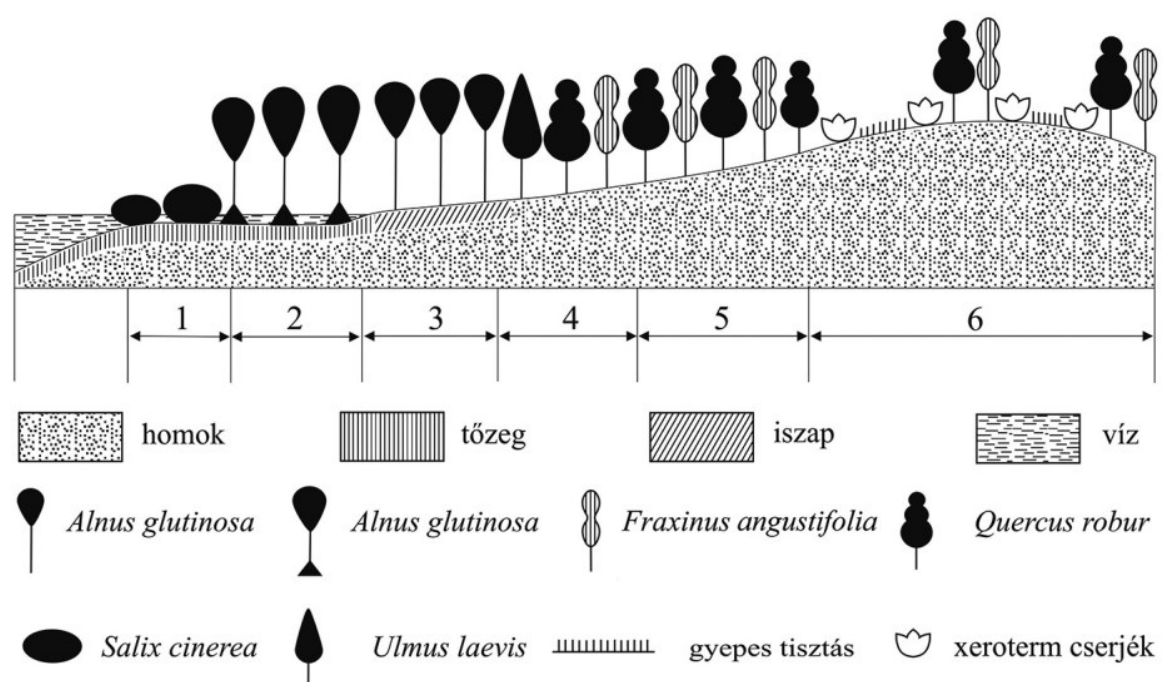

1. ábra. Részlet a Nyírség vegetáció-keresztmetszetéből

1: füzláp (Calamagrostio-Salicetum cinereae); 2: magyar kőrises égerláp (Fraxino pannonicae-Alnetum glutinosae); 3: égerliget (Paridi quadrifoliae-Alnetum glutinosae); 4: tölgy-kőrisszil liget (Fraxino pannonicae-Ulmetum); 5: gyöngyvirágos-tölgyes (Convallario-Quercetum roboris); 6: homokpusztai tölgyes (Melampyro debreceniensi-Quercetum roboris).

A cserjeszint közepesen, vagy erösen fejlett. Borítása 40-70\%, magassága pedig 2,5-5 m. Állandó (K IV-V) fajai a következők: Cornus sanguinea, Corylus avellana, Crataegus monogyna, Fraxinus angustifolia, Sambucus nigra, Ulmus minor. Jelentősebb tömeget (A-D 3-4) csak a Corylus avellana és a Sambucus nigra ér el. Az újulat borítása 3-40\%. Állandó (K IV-V) fajai az alábbiak: Cornus sanguinea, Crataegus monogyna, Euonymus europaeus, Fraxinus angustifolia, Ligustrum vulgare, Rubus caesius, Sambucus nigra, Ulmus minor, Viburnum opulus. Nagyobb tömegben csak a Rubus caesius fordul elő (1-2. táblázat).

A gyepszint borítása 70-90\%. Viszonylag állandó (K IV-V) fajai a következők: Aegopodium podagraria, Brachypodium sylvaticum, Chaerophyllum temulum, Circaea lutetiana, Cucubalus baccifer, Dactylis polygama, Festuca gigantea, Galium aparine, Geranium robertianum, Geum urbanum, Heracleum sphondylium, Humulus lupulus, Lapsana communis, Lysimachia nummularia, Milium effusum, Moehringia trinervia, Polygonatum latifolium, Stachys sylvatica, Torilis japonica, Urtica dioica. Fáciest (A-D 3-4) az Allium ursinum, a Brachypodium sylvaticum, és a Ranunculus ficaria képez (1-2. táblázat). 


\section{Fajkombináció}

\section{Állandósági osztályok}

A vizsgált égerligetekböl - a tíz cönológiai felvétel alapján 22 konstans (K V) és 12 szubkonstans (K IV) faj került elő: - K V: Alnus glutinosa, Brachypodium sylvaticum, Chaerophyllum temulum, Circaea lutetiana, Cornus sanguinea, Crataegus monogyna, Cucubalus baccifer, Euonymus europaeus, Festuca gigantea, Fraxinus angustifolia, Galium aparine, Geranium robertianum, Geum urbanum, Lapsana communis, Ligustrum vulgare, Lysimachia nummularia, Milium effusum, Moehringia trinervia, Sambucus nigra, Stachys sylvatica, Ulmus minor, Viburnum opulus. - K IV: Aegopodium podagraria, Corylus avellana, Dactylis polygama, Frangula alnus, Glechoma hederacea, Heracleum sphondylium, Humulus lupulus, Polygonatum latifolium, Quercus robur, Rubus caesius, Torilis japonica, Urtica dioica. A felvételi anyagban ezen kívül 19 akcesszórikus (K III), 25 szubakcesszórikus (K II) és 60 akcidens (K I) faj is szerepel (1. táblázat; 2. ábra). A fenti adatok szerint tehát az akcidens (K I) fajok mellett a konstans (K V) elemeknél van egy-egy kiugró érték.

\section{Karakterfajok aránya}

A társulás felépítésében jelentős szerepet játszanak a mezofil lomberdei elemek, a Fagetalia fajok: - K V: Circaea lutetiana, Milium effusum, Moehringia trinervia, Stachys sylvatica. - K IV: Aegopodium podagraria. - K III: Carex sylvatica, Listera ovata, Polygonatum multiflorum, Pulmonaria officinalis, Viola reichenbachiana. - K II: Allium ursinum. - K I: Anemone ranunculoides, Athyrium filix-femina, Cardamine bulbifera, Carpinus betulus, Cerasus avium, Corydalis cava, Dryopteris filix-mas, Epipactis helleborine agg., Galeopsis speciosa, Hedera helix, Lathraea squamaria, Lilium martagon. A Fagetalia jellegü fajok 12,33\% csoportrészesedést és 13,35\% csoporttömeget mutatnak, arányuk a Börzsönyből ismert Aegopodion-Alnetum-nál jóval alacsonyabb (1. és 4. táblázat; 3 . ábra).

Ugyancsak jelentősek a keményfás ligeterdők karakterfajai, az Alnion incanae jellegü elemek: - K V: Festuca gigantea, Fraxinus angustifolia, Viburnum opulus. - K IV: Frangula alnus. - K II: Carex remota, Elymus caninus, Populus alba, Rumex sanguineus, Ulmus laevis. - K I: Impatiens noli-tangere, Malus sylvestris, Oenanthe banatica, Ribes rubrum. E növények $10,58 \%$ csoportrészesedést és $25,53 \%$ csoporttömeget mutatnak, arányuk tehát hasonló, mint a Szigetközben és a Börzsönyben (1. és 4. táblázat).

Figyelemre méltók a Quercetea pubescentis-petraeae jellegü elemek jelenléte, bár ezek többsége a Querco-Fagetea osztály karakterfajaival közös. Ilyen Quercetea (p. maj.p. Querco-Fagetea) jellegü fajok a következök: - K V: Brachypodium sylvaticum, Crataegus monogyna, Euonymus europaeus, Ligustrum vulgare, Ulmus minor. - K IV: Corylus avellana, Dactylis polygama, Heracleum sphondylium, Polygonatum latifolium. - K III: Acer campestre, Fallopia dumetorum, Rhamnus catharticus, Viola mirabilis. - K II: Clinopodium vulgare, Convallaria majalis, Galeopsis pubescens, Rosa canina, Viola suavis. - K I: Bromus ramosus, Carex spicata, Euonymus verrucosus, Fragaria vesca, Platanthera bifolia, Poa nemoralis, Populus tremula, Prunus spinosa, Pulmonaria mollissima, Quercus cerris, Symphytum tuberosum, Veronica chamaedrys. Az ilyen Quercetea jellegű növények 12,47\% csoportrészesedést és 7,39\% csoporttömeget mutatnak. Csoportrészesedésük a Nyírségben jóval nagyobb, mint a Börzsönyben (4. táblázat; 4. ábra).

A másik kérdés az, hogy a Nyírség égerligetei mennyire különíthetők el a szomszédos tölgy-kőris-szil ligetektől (Fraxino pannonicae-Ulmetum)? A karakterfajok arányát tekintve az égerligetekben több a Cypero-Phragmitea (5. ábra), a Salicetea purpureae (6. 


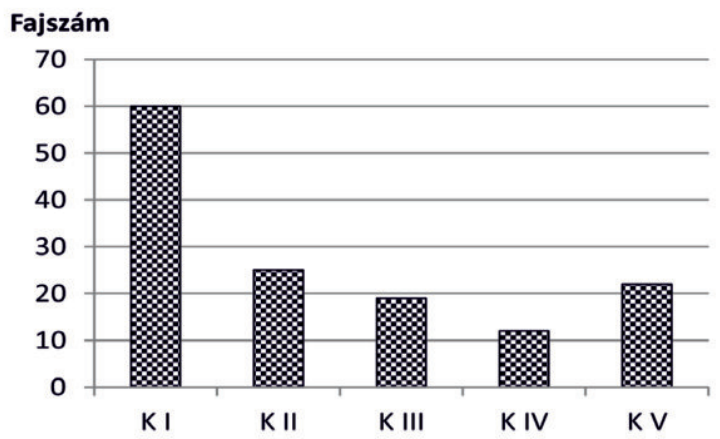

2. ábra: Állandósági osztályok eloszlása

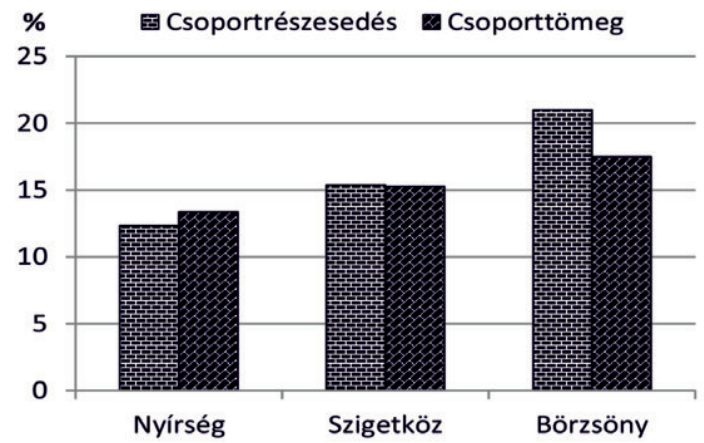

3. ábra: Fagetalia fajok aránya a Nyírség, a Szigetköz és a Börzsöny égerligeteiben Nyírség: Paridi quadrifoliae-Alnetum glutinosae (Kevey és Papp ined.: 10 felv.)

Szigetköz: Paridi quadrifoliae-Alnetum glutinosae (Kevey 2008: 25 felv.)

Börzsöny: Aegopodio-Alnetum glutinosae (Nagy 1997: 15 felv.)

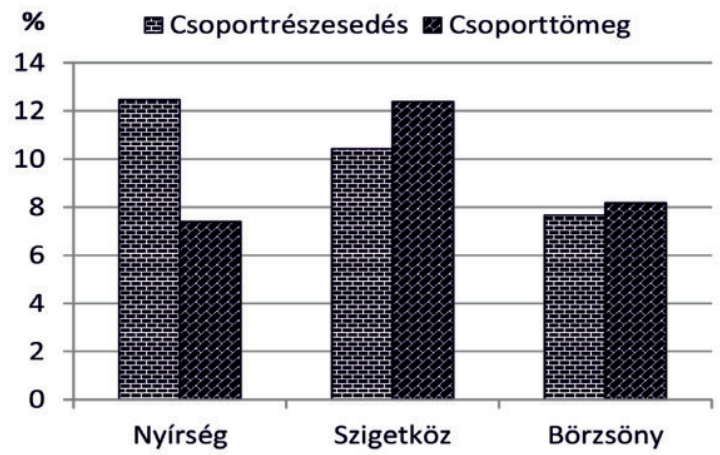

4. ábra: Quercetea pubescentis-petraeae fajok aránya a Nyírség, a Szigetköz és a Börzsöny égerligeteiben

Nyírség: Paridi quadrifoliae-Alnetum glutinosae (Kevey és Papp ined.: 10 felv.)

Szigetköz: Paridi quadrifoliae-Alnetum glutinosae (Kevey 2008: 25 felv.)

Börzsöny: Aegopodio-Alnetum glutinosae (Nagy 1997: 15 felv.) 


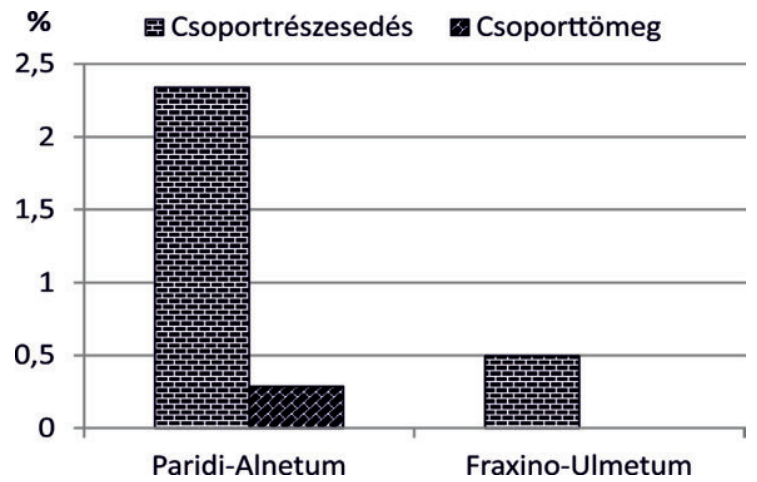

5. ábra: Cypero-Phragmitea s.l. fajok aránya a Nyírség égerligeteiben és tölgy-kőris-szil ligeteiben

Paridi-Alnetum: Paridi quadrifoliae-Alnetum glutinosae, Nyírség (Kevey és Papp ined.: 10 felv.) Fraxino-Ulmetum: Fraxino pannonicae-Ulmetum, Nyírség (Kevey et al. 2017: 25 felv.)

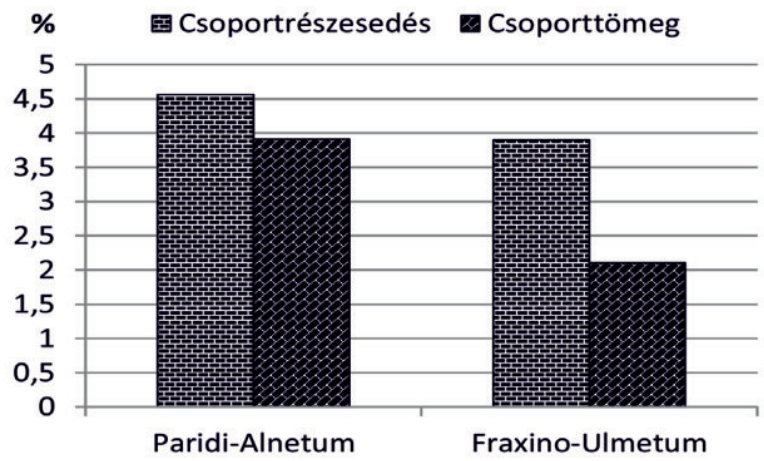

6. ábra: Salicetea purpureae s.l. fajok aránya a Nyírség égerligeteiben és tölgy-kőris-szil ligeteiben

Paridi-Alnetum: Paridi quadrifoliae-Alnetum glutinosae, Nyírség (Kevey és Papp ined.: 10 felv.) Fraxino-Ulmetum: Fraxino pannonicae-Ulmetum, Nyírség (Kevey et al. 2017: 25 felv.)

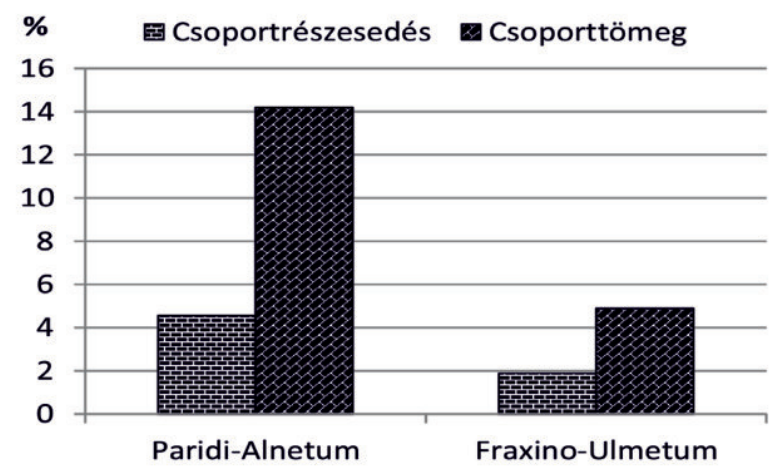

7. ábra: Alnetea glutinosae s.l. fajok aránya a Nyírség égerligeteiben és tölgy-kőris-szil ligeteiben

Paridi-Alnetum: Paridi quadrifoliae-Alnetum glutinosae, Nyírség (Kevey és Papp ined.: 10 felv.) Fraxino-Ulmetum: Fraxino pannonicae-Ulmetum, Nyírség (Kevey et al. 2017: 25 felv.) 


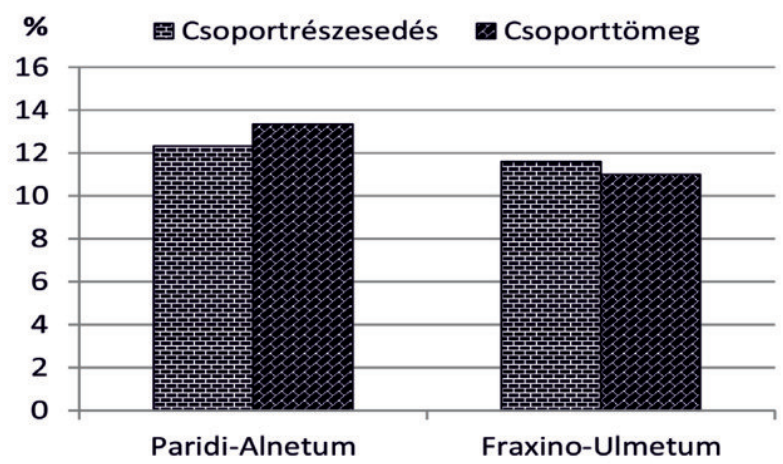

8. ábra: Fagetalia fajok aránya a Nyírség égerligeteiben és tölgy-kőris-szil ligeteiben Paridi-Alnetum: Paridi quadrifoliae-Alnetum glutinosae, Nyírség (Kevey és Papp ined.: 10 felv.) Fraxino-Ulmetum: Fraxino pannonicae-Ulmetum, Nyírség (Kevey et al. 2017: 25 felv.)

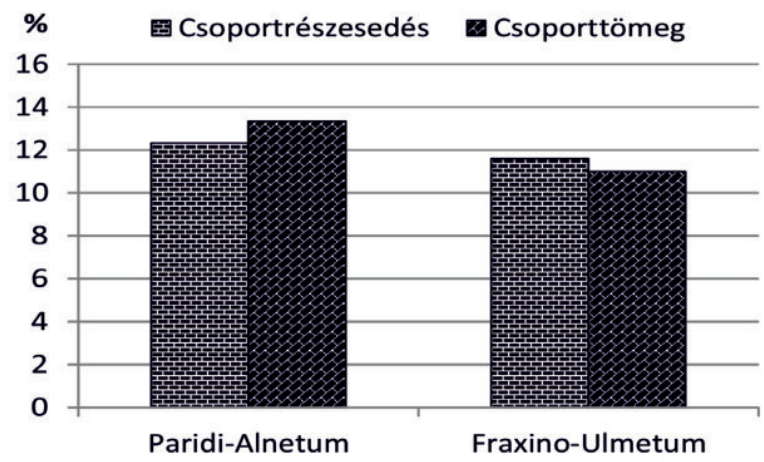

9. ábra: Alnion incanae fajok aránya a Nyírség égerligeteiben és tölgy-kőris-szil ligeteiben Paridi-Alnetum: Paridi quadrifoliae-Alnetum glutinosae, Nyírség (Kevey és Papp ined.: 10 felv.) Fraxino-Ulmetum: Fraxino pannonicae-Ulmetum, Nyírség (Kevey et al. 2017: 25 felv.)

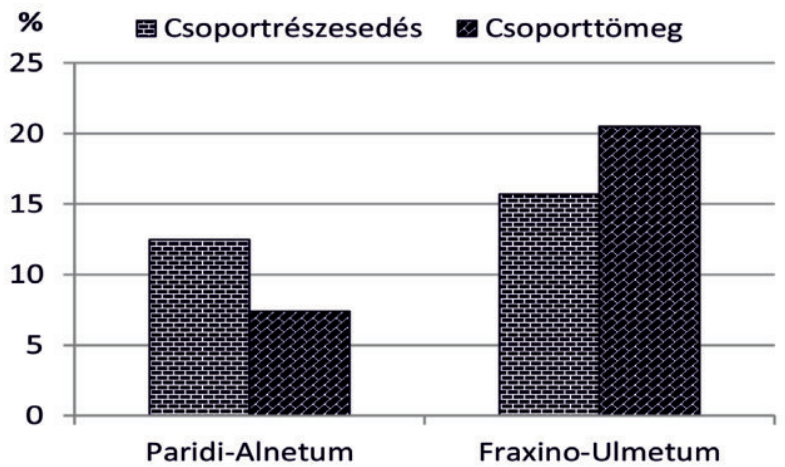

10. ábra: Quercetea pubescentis-petraeae fajok aránya a Nyírség égerligeteiben és tölgy-kőris-szil ligeteiben

Paridi-Alnetum: Paridi quadrifoliae-Alnetum glutinosae, Nyírség (Kevey és Papp ined.: 10 felv.) Fraxino-Ulmetum: Fraxino pannonicae-Ulmetum, Nyírség (Kevey et al. 2017: 25 felv.) 
ábra), az Alnetea glutinosae (7. ábra), a Fagetalia (8. ábra) és az Alnion incanae (9. ábra) elem, viszont a Quercetea pubescentis-petraeae fajok a tölgy-köris-szil ligetekben lényegesen nagyobb arányt mutatnak (10. ábra).

\section{Differenciális fajok}

A Nyírség égerligetei és tölgy-köris-szil ligeterdei között számos olyan differenciális fajt sikerült kimutatni, amelyek a két asszociáció között legalább két állandósági fokozatnyi különbséget jeleznek. Az égerligeteknek így 25, a tölgy-kőris-szil ligeteknek pedig 22 ilyen differenciális fajuk került elő (5. táblázat).

\section{Sokváltozós elemzések eredményei}

A Nyírség (Kevey - Papp ined.), a Szigetköz (Kevey 2008) és a Börzsöny (NAGY 1997) égerligeteinek összehasonlításával a dendrogramon (11. ábra) a nyírségi és a szigetközi anyag viszonylag közel áll egymáshoz, míg a börzsönyi felvételek jobban elkülönülnek. Hasonló összefüggés látható az ordinációs diagramon (12. ábra), bár itt a szigetközi és a börzsönyi felvételek hasonló távolságban helyezkednek el a nyírségiektől.

A Nyírség égerligeteinek és tölgy-kőris-szil ligeteinek összehasonlításával a felvételek két csoportba tömörülnek (13. ábra). Az elkülönülés azonban nem tökéletes, ugyanis a tölgy-kőris-szil ligetekből három felvétel az égerligetek csoportjába került. Ez olvasható le az ordinációs diagramról is (14. ábra).

\section{Természetvédelmi eredmények}

A Nyírség jelentős részét ma már kultúrerdők borítják. Ezek rengetegében a vizsgált égerligetek (Paridi quadrifoliae-Alnetum glutinosae) értékes mozaikként, mint oázisok különülnek el. Az égerligetekből ugyan csak 10 cönológiai felvételt sikerült készítenünk, de ezekböl 6 védett növényfaj előkerült: K III: Listera ovata. - K I: Dryopteris carthusiana, Epipactis helleborine agg., Lilium martagon, Platanthera bifolia, Veratrum album. Mellettük említésre méltó még a Nyírségben elterjedésének északi határát elérő Tilia tomentosa, valamint az Oenanthe banatica lokális elöfordulása.

Dendrológiai értéket képeznek egyes fává nőtt cserjék (Acer tataricum, Corylus avellana), amelyek törzsátméröje helyenként a $40 \mathrm{~cm}$-t is elérheti.

Flóraszennyező hatást fejtenek ki a felvételekben is szereplő egyes adventív növényfajok: K III: Acer negundo, Celtis occidentalis. - K II: Fraxinus pennsylvanica. - K I: Juglans nigra, Morus alba, Populus $\times$ euramericana, Quercus rubra, Robinia pseudoacacia.

A Terem melletti „Nagyfenék” ma már Natura 2000 terület, a Nyírábrányhoz tartozó „Mogyorósi-erdő” pedig a Hajdusági Tájvédelmi Körzet része. Sajnos a Mérk melletti „Vadaskerti-erdo”" mindeddig semmilyen védelemben nem részesült, pedig fokozott védelmet érdemelne (KEVEY et al. 2017.

\section{Diszkusszió}

A három táj égerligeteinek összehasonlításakor az egyes paramétereknél eltérő adatokat kaptunk, viszont úgy tünik, hogy a nyírségi anyag közelebb áll a szigetközihez, míg a Börzsöny felvételei viszonylag jól elkülönülnek az elöbbi kettőtől. Erre jó példa, hogy a Börzsönyben van a legtöbb a Fagetalia (4. táblázat; 2. ábra) és a legkevesebb Quercetea pubescentis-petraeae (4. táblázat; 3. ábra) jellegü elem. Ennek magyarázata lehet az, hogy a Nyírség és a Szigetköz az Alföld része, míg a Börzsöny az Északi- 


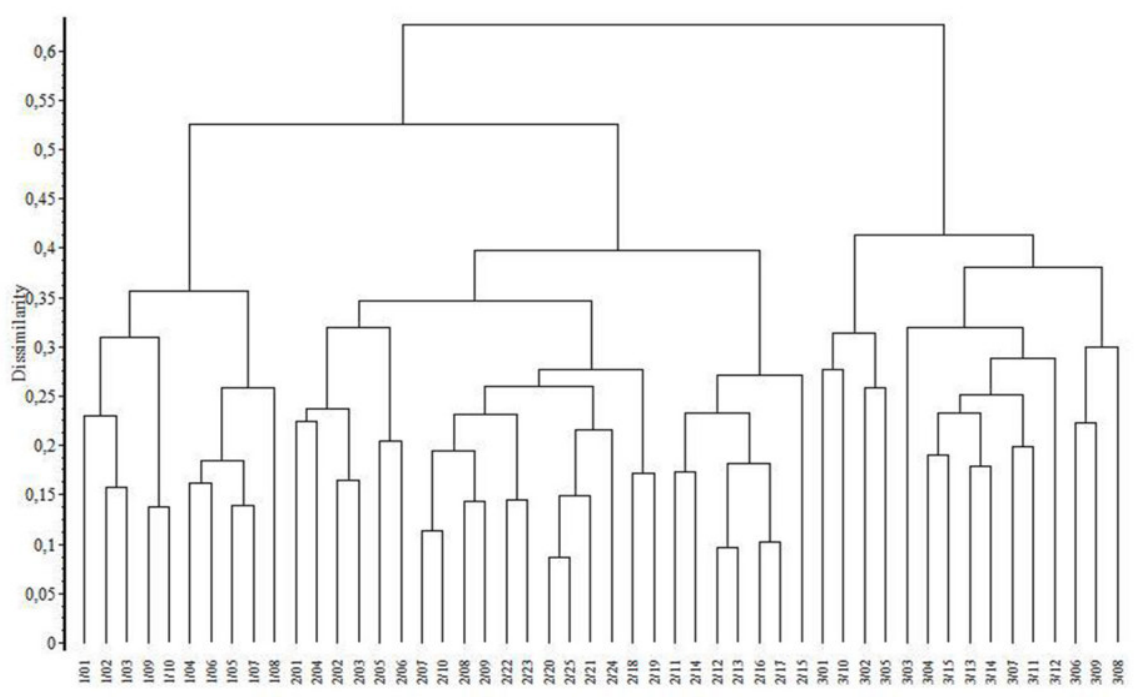

11. ábra: A Nyírség, a Szigetköz és a Börzsöny égerligeteinek dendrogramja (hasonlósági index: Baroni-Urbani-Buser; osztályozó módszer: teljes lánc) 1/1-10: Paridi quadrifoliae-Alnetum glutinosae, Nyírség (Kevey és Papp ined.)

2/1-25: Paridi quadrifoliae-Alnetum glutinosae, Nyírség (Kevey 2008) 3/1-15: Aegopodio-Alnetum glutinosae, Börzsöny (Nagy 1997)

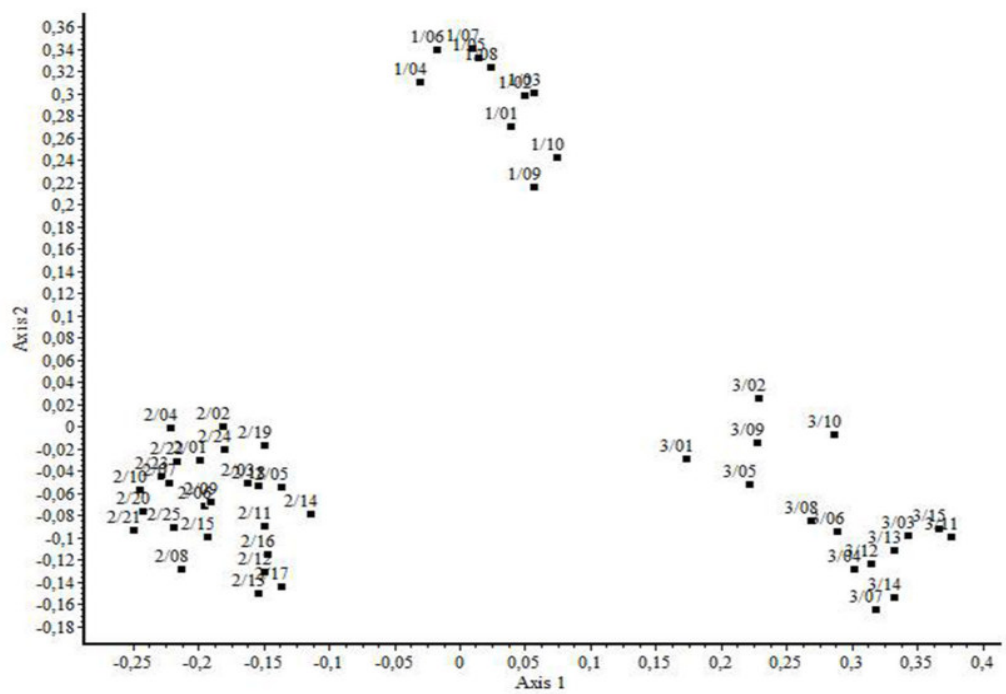

12. ábra: A Nyírség, a Szigetköz és a Börzsöny égerligeteinek ordinációs diagramja (hasonlósági index: Baroni-Urbani-Buser; ordinációs módszer: főkoordináta-analízis)

1/1-10: Paridi quadrifoliae-Alnetum glutinosae, Nyírség (Kevey és Papp ined.)

2/1-25: Paridi quadrifoliae-Alnetum glutinosae, Nyírség (Kevey 2008) 3/1-15: Aegopodio-Alnetum glutinosae, Börzsöny (Nagy 1997) 


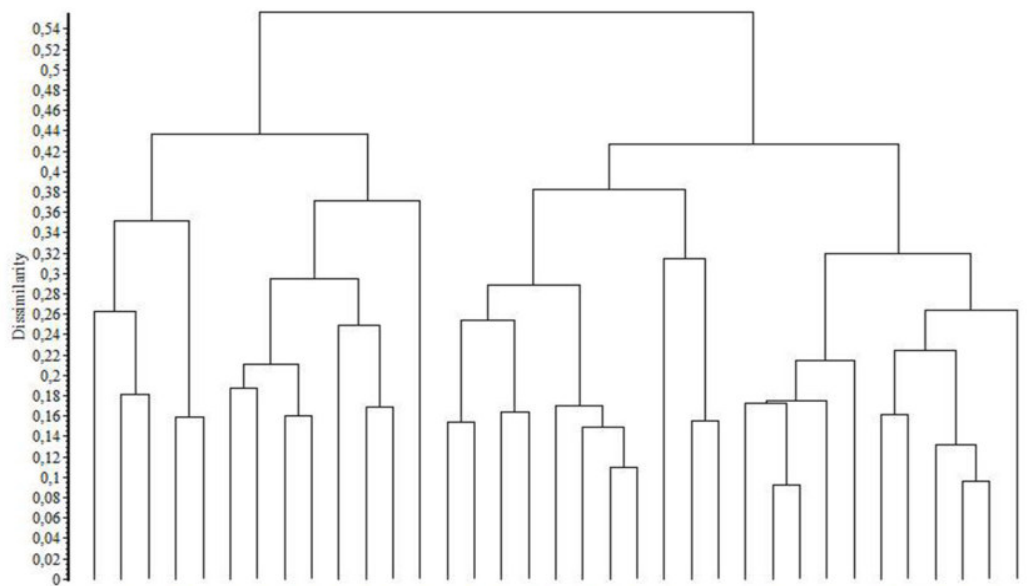

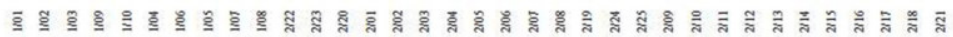

13. ábra: A Nyírség égerligeteinek és tölgy-kőris-szil ligeteinek dendrogramja (hasonlósági index: Baroni-Urbani-Buser; osztályozó módszer: teljes lánc) 1/1-10: Paridi quadrifoliae-Alnetum glutinosae, Nyírség (Kevey és Papp ined.) 2/1-25: Fraxino pannonicae-Ulmetum, Nyírség (Kevey et al. 2017)

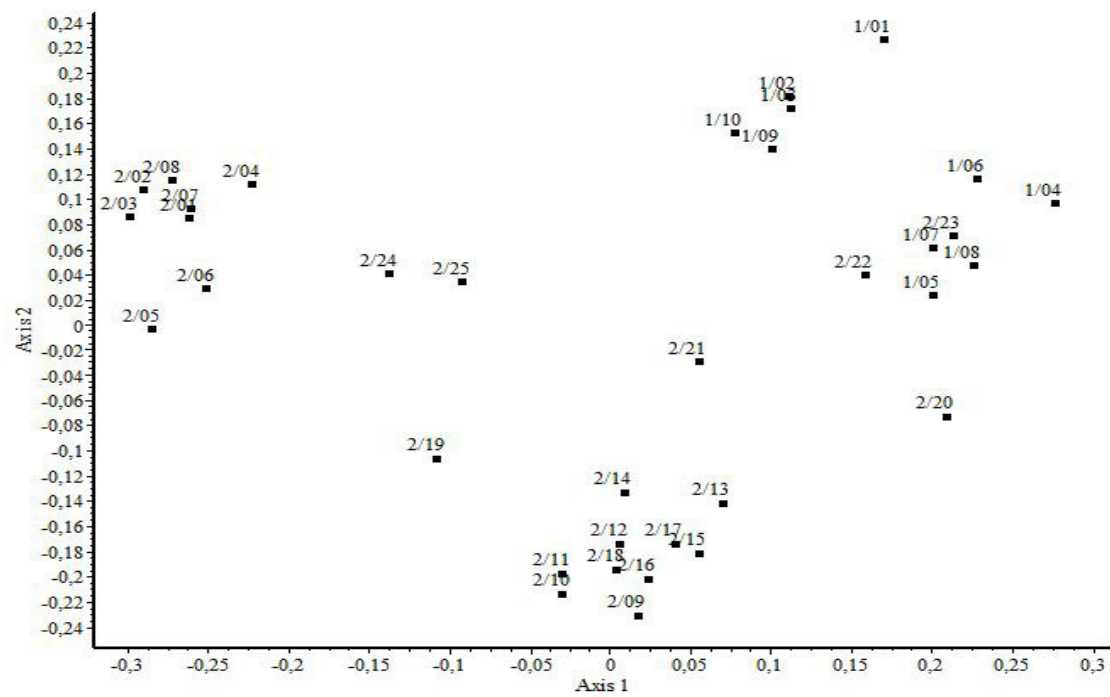

14. ábra: A Nyírség égerligeteinek és tölgy-kőris-szil ligeteinek ordinációs diagramja (hasonlósági index: Baroni-Urbani-Buser; osztályozó módszer: teljes lánc) 1/1-10: Paridi quadrifoliae-Alnetum glutinosae, Nyírség (Kevey és Papp ined.) 2/1-25: Fraxino pannonicae-Ulmetum, Nyírség (Kevey et al. 2017) 
középhegységhez tartozik, ahol sokkal jobban érvényesül a szubmontán hatás. Az elkülönülést a sokváltozós elemzések is alátámasztják. Az ordinációs diagramon (11. ábra) ugyan a három táj felvételei még egymástól egyforma távolságra levő csoportot képeznek, a dendrogramon (10. ábra) viszont a Börzsöny felvételei szépen elkülönülnek a nyírségi és a szigetközi anyagtól.

A másik kérdés az, hogy a Nyírség égerligetei mennyire különíthetők el a szomszédos tölgy-kőris-szil ligetektől? A karakterfajok arányát tekintve az égerligetekben több a Cypero-Phragmitea (4. ábra), a Salicetea purpureae (5. ábra), az Alnetea glutinosae (6. ábra), a Fagetalia (7. ábra) és az Alnion incanae (8. ábra) elem, viszont a Quercetea pubescentis-petraeae (9. ábra) fajok lényegesen kisebb arányt mutatnak. Ennek magyarázata az, hogy az égerligetek mélyebb termőhelyen fordulnak elö, mint a tölgy-kőris-szil ligetek, ezért a fenti nedvesség igényü szüntaxonok (Cypero-Phragmitea s.l., Salicetea purpureae s.l., Alnetea s.l., Fagetalia, Alnion incanae) nagyobb arányban fordulnak elö, mint a tölgy-kőris-szil ligetekben. A két asszociáció közötti különbséget a differenciális fajok száma (5. táblázat), és a sokváltozós eredmények is alátámasztják. A dendrogramon és az ordinációs diagramon a két asszociáció felvételei két csoportba tömörülnek. Az elkülönülés azonban néhány átmeneti jellegü felvétel miatt nem tökéletes (12-13. ábra).

Összegezve a fentieket, a Nyírség fragmentális égerligete a Szigetközből leírt Paridi quadrifoliae-Alnetum glutinosae asszociációval azonosítható. Szüntaxonómiai helye az alábbi módon vázolható:

Divisio: Querco-Fagea Jakucs 1967

Classis: Querco-fagetea Br.-Bl. et Vlieger in Vlieger 1937 em.

Borhidi in Borhidi et Kevey 1996

Ordo: Fagetalia sylvaticae Pawłowski in Pawłowski et al. 1928

Alliance: Alnion incanae Pawłowski in Pawłowski et al. 1928

Suballiance: Alnion glutinosae-incanae Oberdorfer 1953

Associatio: Paridi quadrifoliae-Alnetum glutinosae Kevey

in Borhidi et Kevey 1996

\section{Összefoglalás}

Jelen tanulmány tíz cönológiai felvétellel mutatja be a Nyírség homokvidékének égerligeteit. Állományai a tölgy-kőris-szil ligetek (Fraxino pannonicae-Ulmetum), és a magyar kőrises égerlápok (Fraxino pannonicae-Alnetum glutinosae) között helyezkednek el. A felmért állományok a Szigetközből leírt Paridi quadrifiliae-Alnetum glutinosae Kevey in Borhidi et Kevey 1996 asszociációval azonosíthatók és elkülöníthetők a Magyar-középhegység Aegopodio-Alnetum glutinosae Kárpáti V., Kárpáti I. et Jurko ex Šomšák 1961 nevű társulástól. 


\section{Rövidítések}

A1: felső lombkoronaszint; A2: alsó lombkoronaszint; Adv: Adventiva; AF: AremonioFagion; Agi: Alnenion glutinosae-incanae; Ai: Alnion incanae; Alo: Alopecurion pratensis; APa: Abieti-Piceea; AQ: Aceri tatarici-Quercion; Ara: Arrhenatheretalia; Arc: Arction lappae; Ata: Alnetalia glutinosae; B1: cserjeszint; B2: újulat; Ber: Berberidion; Bia: Bidentetalia; Bon: Bidention tripartiti; C: gyepszint; CG: CallunoGenistion; Cgr: Caricenion gracilis; Che: Chenopodietea; ChS: Chenopodio-Scleranthea; Cn: Calystegion sepium; Cp: Carpinenion betuli; Des: Deschampsion caespitosae; Epa: Epilobietalia; Epn: Epilobion angustifolii; F: Fagetalia sylvaticae; FBt: FestucoBrometea; FiC: Filipendulo-Cirsion oleracei; FPi: Festuco-Puccinellietalia; Fru: Festucion rupicolae; GA: Galio-Alliarion; I: Indifferens; ined.: ineditum (kiadatlan közlés); Mag: Magnocaricion; Moa: Molinietalia coeruleae; MoA: Molinio-Arrhenatherea; Moa: Molinio-Juncetea; NA: Nardo-Agrostion tenuis; Onn: Onopordion acanthii; Pla: Plantaginetalia majoris; Pna: Populenion nigro-albae; PQ: Pino-Quercion; Prf: Prunion fruticosae; Pru: Prunetalia spinosae; Pte: Phragmitetea; Qc: Quercetalia cerridis; Qfa: Quercion farnetto; QFt: Querco-Fagetea; Qpp: Quercetea pubescentis-petraeae; Qr: Quercetalia roboris; S: summa (összeg); Sal: Salicion albae; SaS: Sambuco-Salicion capreae Sea: Secalietea; s.1.: sensu lato (tágabb értelemben); Spu: Salicetalia purpureae; Ulm: Ulmenion; VP: Vaccinio-Piceetea. 


\section{1. táblázat: Paridi quadrifoliae-Alnetum glutinosae, Nyírség}

\begin{tabular}{|c|c|c|c|c|c|c|c|c|c|c|c|c|c|c|}
\hline Szüntaxon/Faj & Szint & 1 & 2 & 3 & 4 & 5 & 6 & 7 & 8 & 9 & 10 & A-D & $\mathrm{K}$ & $\mathrm{K} \%$ \\
\hline \multirow{3}{*}{\multicolumn{15}{|c|}{$\begin{array}{l}\text { 5. Querco-Fagea } \\
\text { 5.1. Salicetea purpureae } \\
\text { 5.1.1. Salicetalia purpureae }\end{array}$}} \\
\hline & & & & & & & & & & & & & & \\
\hline & & & & & & & & & & & & & & \\
\hline Populus nigra & A 1 & - & - & + & - & & - & - & - & & - & + & 1 & 10 \\
\hline \multicolumn{15}{|l|}{ 5.1.1.1. Salicion albae } \\
\hline Cucubalus baccifer ( $\mathrm{Cn}, \mathrm{UIm}$ ) & $\mathrm{C}$ & - & + & + & + & + & + & + & + & + & + & + & V & 90 \\
\hline \multirow[t]{3}{*}{ Humulus lupulus ( $\mathrm{Cn}, \mathrm{Ata}, \mathrm{Ai}$ ) } & B1 & + & + & - & - & - & - & - & - & - & - & + & 1 & 20 \\
\hline & C & + & + & + & + & + & + & + & + & - & - & + & IV & 80 \\
\hline & S & + & + & + & + & + & + & + & + & - & - & + & IV & 80 \\
\hline Carduus crispus (Cn) & c & - & - & - & - & - & - & - & - & + & + & + & 1 & 20 \\
\hline \multicolumn{15}{|l|}{ 5.2. Alnetea glutinosae } \\
\hline \multicolumn{15}{|l|}{ 5.2.1. Alnetalia glutinosae } \\
\hline \multirow[t]{5}{*}{ Alnus glutinosa (Ai, Agi) } & A1 & 4 & 4 & 3 & 4 & 3 & 4 & 4 & 4 & 3 & 4 & $3-4$ & V & 100 \\
\hline & $\mathrm{A} 2$ & 1 & - & 1 & 1 & - & 1 & 1 & - & 1 & 2 & $1-2$ & IV & 70 \\
\hline & B1 & + & - & - & + & & + & + & - & & + & + & III & 50 \\
\hline & B2 & - & - & - & + & - & - & + & + & - & - & + & 11 & 30 \\
\hline & $\mathrm{S}$ & 4 & 4 & 3 & 4 & 3 & 4 & 4 & 4 & 3 & 5 & $3-5$ & V & 100 \\
\hline Dryopteris carthusiana (F, Agi, Or, VP) & C & - & - & + & - & - & - & - & - & - & + & + & 1 & 20 \\
\hline \multicolumn{15}{|l|}{ 5.3. Querco-Fagetea } \\
\hline Brachypodium sylvaticum (Qpp) & C & + & + & 1 & 2 & 2 & 2 & 3 & 1 & 2 & + & +-3 & V & 100 \\
\hline \multirow[t]{3}{*}{ Cornus sanguinea (Qpp) } & B1 & 2 & 2 & 1 & + & 1 & 1 & 1 & + & 1 & 1 & +-2 & V & 100 \\
\hline & B2 & + & + & + & + & + & + & + & + & + & + & + & V & 100 \\
\hline & $\mathrm{S}$ & 2 & 2 & 1 & + & 1 & 1 & 1 & + & 1 & 1 & +-2 & V & 100 \\
\hline \multirow[t]{3}{*}{ Crataegus monogyna (Qpp) } & B1 & 2 & 1 & + & - & - & - & 1 & + & + & + & +-2 & IV & 70 \\
\hline & B2 & + & + & + & + & + & + & + & + & + & + & + & V & 100 \\
\hline & S & 2 & 1 & + & + & + & + & 1 & + & + & + & +-2 & v & 100 \\
\hline \multirow[t]{3}{*}{ Euonymus europaeus (Qpp) } & B1 & + & 1 & - & - & - & - & - & + & + & + & +-1 & 111 & 50 \\
\hline & B2 & 1 & + & + & + & + & + & + & + & + & + & +-1 & V & 100 \\
\hline & $S$ & 1 & 1 & + & + & + & + & + & + & + & + & +-1 & V & 100 \\
\hline Geranium robertianum (Epa) & C & + & 1 & 2 & + & 2 & 2 & 2 & 2 & + & + & +-2 & V & 100 \\
\hline Geum urbanum (Epa, Cp, Qpp) & C & + & + & + & 1 & + & + & + & + & + & + & +-1 & V & 100 \\
\hline Lapsana communis (Qpp, GA, Epa) & $\mathrm{C}$ & + & + & + & + & + & + & + & + & + & + & + & V & 100 \\
\hline \multirow[t]{5}{*}{ Ulmus minor (Ai, Ulm, Qpp) } & A1 & - & - & - & - & 1 & - & - & - & & - & 1 & 1 & 10 \\
\hline & $\mathrm{A} 2$ & - & - & - & - & - & - & - & - & + & 1 & +-1 & 1 & 20 \\
\hline & B1 & + & 2 & + & - & - & 1 & - & + & + & + & +-2 & IV & 70 \\
\hline & B2 & - & + & + & + & + & + & + & + & + & + & + & V & 90 \\
\hline & $\mathrm{S}$ & + & 2 & + & + & 1 & 1 & + & + & 1 & 1 & +-2 & V & 100 \\
\hline \multirow[t]{3}{*}{ Ligustrum vulgare (Cp, Qpp) } & B1 & 1 & + & + & - & + & + & + & - & - & - & +-1 & III & 60 \\
\hline & B2 & + & + & + & + & + & + & + & - & + & + & + & V & 90 \\
\hline & $\mathrm{S}$ & 1 & + & + & + & + & + & + & - & + & + & +-1 & v & 90 \\
\hline \multirow[t]{4}{*}{ Corylus avellana (Qpp) } & $A 2$ & - & - & - & - & - & - & - & - & 1 & 1 & 1 & 1 & 20 \\
\hline & B1 & - & 2 & 1 & + & + & + & + & - & 3 & 4 & +-4 & IV & 80 \\
\hline & B2 & - & - & - & + & - & + & + & - & + & + & + & III & 50 \\
\hline & $\mathrm{s}$ & - & 2 & 1 & + & + & + & + & - & 3 & 4 & +-4 & IV & 80 \\
\hline Heracleum sphondylium (Qpp, MoA) & $\mathrm{C}$ & + & + & - & + & + & + & + & + & - & + & + & IV & 80 \\
\hline \multirow[t]{4}{*}{ Quercus robur (Ai, Cp, Qpp) } & A1 & 1 & + & - & - & + & - & - & - & - & - & +-1 & 11 & 30 \\
\hline & A2 & - & - & - & - & - & + & - & - & - & - & + & 1 & 10 \\
\hline & $\mathrm{B} 2$ & - & - & + & + & - & + & - & + & + & - & + & III & 50 \\
\hline & $S$ & 1 & + & + & + & + & + & - & + & + & - & +-1 & IV & 80 \\
\hline Dactylis polygama (Qpp, Cp) & $\mathrm{C}$ & + & - & - & + & + & + & + & - & + & + & + & IV & 70 \\
\hline
\end{tabular}




\section{1. táblázat: Paridi quadrifoliae-Alnetum glutinosae, Nyírség folytatása}

\begin{tabular}{|c|c|c|c|c|c|c|c|c|c|c|c|c|c|}
\hline Szüntaxon/Faj & Szint & 1 & 3 & 34 & 5 & 6 & 7 & 8 & 91 & 10 & A-D & $\mathrm{K}$ & $\mathrm{K} \%$ \\
\hline Polygonatum latifolium (Qpp) & $\mathrm{C}$ & - & + & +- & + & 2 & + & + & 1 & + & $+-2 \quad$ & IV & 70 \\
\hline \multirow[t]{4}{*}{ Acer campestre (Qpp) } & A2 & - & - & & & - & & & + & - & + & 1 & 10 \\
\hline & B1 & - & ++ & - & & - & & & + & + & + & $\|$ & 40 \\
\hline & B2 & + & $-\quad+$ & - & & + & & & + & + & +1 & III & 50 \\
\hline & $\mathrm{s}$ & + & + & - & - & + & - & - & 1 & + & $+-1 \quad$ I & III & 60 \\
\hline \multirow[t]{3}{*}{ Rhamnus catharticus (Qpp, Pru) } & B1 & - & - & + & & + & + & & - & - & + & ॥ & 30 \\
\hline & B2 & + & & & + & + & + & + & - & - & +1 & III & 50 \\
\hline & $\mathrm{S}$ & + & - & + & + & + & + & + & - & - & +1 & III & 60 \\
\hline Viola mirabilis (F, Qpp) & c & + & + & - & & + & & & + & + & +1 & III & 60 \\
\hline Ajuga reptans (MoA) & c & + & + & - & - & - & - & - & 1 & + & $+-1 \quad \mid$ & III & 50 \\
\hline Campanula trachelium (Epa, Cp) & c & - & - & + & + & + & + & + & - & - & +1 & III & 50 \\
\hline Fallopia dumetorum (Qpp, GA) & c & - & + & & + & + & + & & + & - & +1 & III & 50 \\
\hline Veronica sublobata & c & - & + & +- & - & - & - & + & 1 & 1 & $+-1 \quad$ & III & 50 \\
\hline Galeopsis pubescens (Qpp, Epa) & c & - & + & - & - & - & + & + & + & - & + & ॥ & 40 \\
\hline Ranunculus ficaria & c & + & + & & & - & & & 4 & 4 & +-4 & ॥ & 40 \\
\hline Scrophularia nodosa (GA, Epa) & c & - & - & + & - & - & - & + & + & + & + & 11 & 40 \\
\hline Viola suavis s.I. (Qpp) & c & - & - & + & - & + & + & - & & + & + & ॥ & 40 \\
\hline Convallaria majalis (Qpp) & $\mathrm{C}$ & - & - & + & 1 & + & & & - & - & +-1 & ॥ & 30 \\
\hline Bromus ramosus agg. (Qpp) & c & + & - & - & - & - & - & - & - & + & + & 1 & 20 \\
\hline Poa nemoralis (Qpp) & C & - & - & - & & & - & - & & + & + & 1 & 20 \\
\hline \multirow[t]{4}{*}{ Populus tremula (Qr, Qc, Ber) } & A1 & - & - & & & + & & & - & - & + & । & 10 \\
\hline & B1 & - & - & - & - & + & - & - & + & - & + & । & 20 \\
\hline & B2 & - & - & - & - & + & - & - & & - & + & । & 10 \\
\hline & $\mathrm{s}$ & - & - & & & 1 & & & + & - & +-1 & 1 & 20 \\
\hline Carex divulsa & c & - & - & - & - & - & - & - & + & - & + & । & 10 \\
\hline Carex spicata (Qpp, Epa) & C & - & - & - & - & + & - & - & & - & + & । & 10 \\
\hline Cruciata glabra & c & - & - & & + & - & & & - & - & + & । & 10 \\
\hline Fragaria vesca (Qpp, Epa) & c & + & - & - & - & - & - & - & - & - & + & । & 10 \\
\hline Mycelis muralis & C & - & + & - & - & & - & - & & - & + & । & 10 \\
\hline Platanthera bifolia (Qpp, PQ, NA, Moa) & c & + & - & - & - & - & - & - & - & - & + & । & 10 \\
\hline Ranunculus auricomus agg. (MoA) & c & - & + & - & - & - & - & - & - & - & + & । & 10 \\
\hline Symphytum tuberosum (Cp, Qpp) & c & - & - & - & - & & - & - & & - & + & । & 10 \\
\hline Veronica chamaedrys (Qpp, Ara) & c & + & - & - & - & - & - & - & - & - & + & । & 10 \\
\hline \multicolumn{14}{|l|}{ 5.3.1. Fagetalia sylvaticae } \\
\hline Circaea lutetiana (Ai) & c & + & + & 2 & + & 1 & + & 2 & + & 1 & +-2 & v & 100 \\
\hline Milium effusum & c & + & + & ++ & + & 1 & + & + & + & + & +-1 & $v$ & 100 \\
\hline Moehringia trinervia & c & - & + & ++ & + & + & + & + & + & + & + & v & 90 \\
\hline Stachys sylvatica (Epa) & c & + & + & 11 & + & - & 1 & 2 & + & + & +-2 & v & 90 \\
\hline Aegopodium podagraria $(\mathrm{Ai}, \mathrm{Cp})$ & c & 2 & 1 & ++ & 1 & 2 & & + & - & - & +-2 & IV & 70 \\
\hline Polygonatum multiflorum (QFt) & c & + & + & - & & + & & & + & + & +1 & III & 60 \\
\hline Viola reichenbachiana & c & + & + & + & & & - & & + & + & +1 & III & 60 \\
\hline Carex sylvatica & c & + & + & - & - & - & - & - & + & + & +1 & III & 50 \\
\hline Listera ovata (Ata, Ai) & c & + & + & - & & - & & & + & + & +1 & III & 50 \\
\hline Pulmonaria officinalis & c & 1 & + & - & & - & & & 1 & 1 & +-1 & III & 50 \\
\hline Allium ursinum & C & 5 & 5 & - & & - & & & - & - & 5 & ॥ & 30 \\
\hline \multirow[t]{3}{*}{ Carpinus betulus (Cp) } & $A 2$ & - & - & & & - & & & + & + & + & 1 & 20 \\
\hline & B2 & - & & & & - & & & + & + & + & 1 & 20 \\
\hline & S & - & - - & - - & - & - & & & & + & + & 1 & 20 \\
\hline
\end{tabular}


1. táblázat: Paridi quadrifoliae-Alnetum glutinosae, Nyírség folytatása

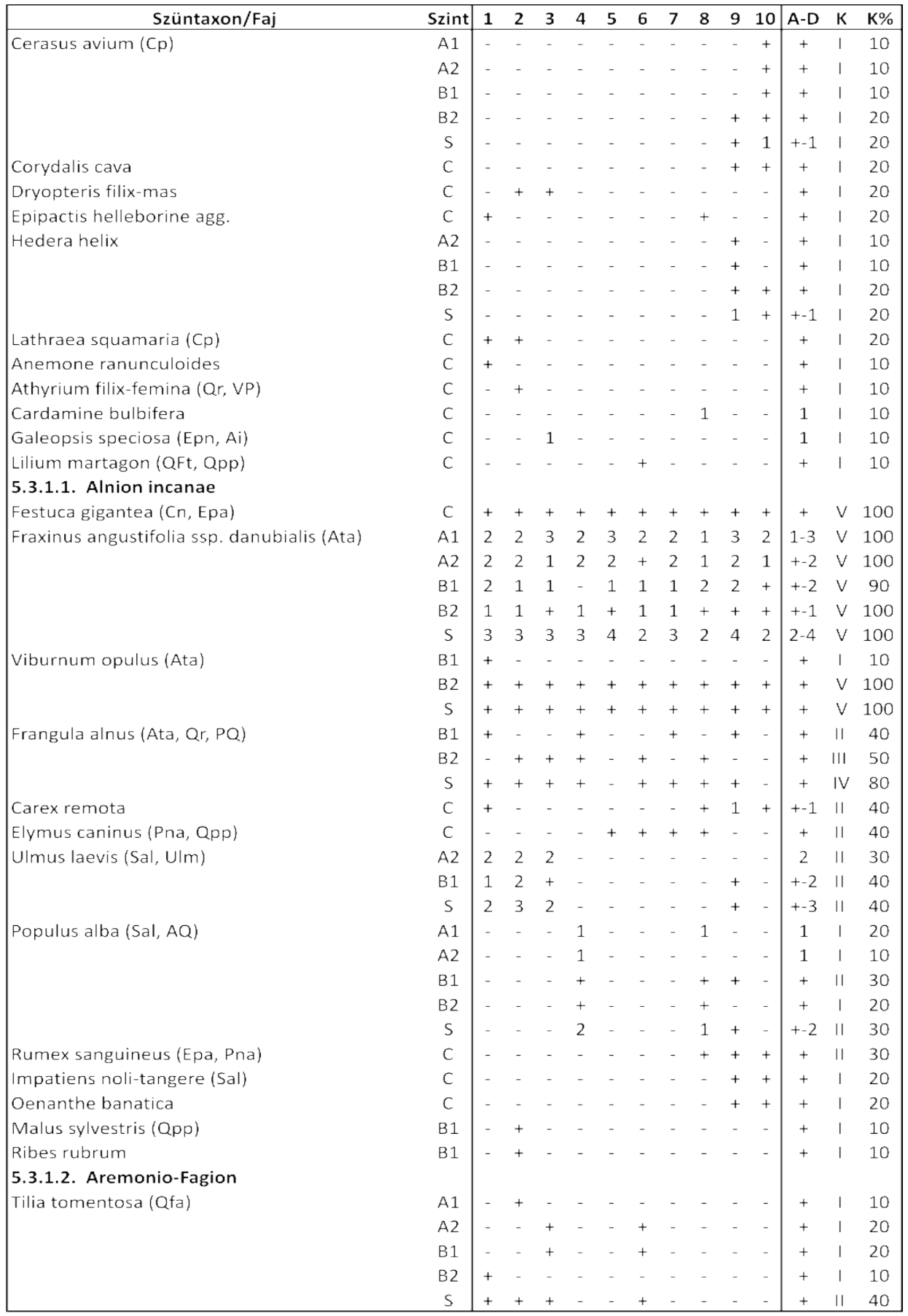


1. táblázat: Paridi quadrifoliae-Alnetum glutinosae, Nyírség folytatása

\begin{tabular}{|c|c|c|c|c|c|c|c|c|c|c|c|c|c|c|}
\hline Szüntaxon/Faj & Szint & 1 & 2 & 3 & 4 & 5 & 6 & 7 & 8 & 9 & 10 & $A-D$ & $\mathrm{~K}$ & $\mathrm{~K} \%$ \\
\hline \multicolumn{15}{|l|}{ 5.4. Quercetea pubescentis-petraeae } \\
\hline Clinopodium vulgare & C & - & + & - & + & - & + & + & - & - & - & + & II & 40 \\
\hline \multirow[t]{3}{*}{ Rosa canina agg. (Pru, Prf) } & B1 & + & & & - & & & & - & & & + & I & 10 \\
\hline & B2 & - & & & - & + & & + & - & & & + & । & 20 \\
\hline & $\mathrm{S}$ & + & - & - & - & + & - & + & - & - & - & + & $\|$ & 30 \\
\hline Euonymus verrucosus (Pru) & B2 & - & - & - & - & - & + & - & - & - & - & + & । & 10 \\
\hline Prunus spinosa (Pru, Prf) & B2 & - & - & - & + & - & - & - & - & - & - & + & I & 10 \\
\hline Pulmonaria mollissima & C & - & - & - & - & - & + & - & - & - & - & + & । & 10 \\
\hline Quercus cerris (Qr, PQ) & B2 & - & - & - & - & - & - & - & - & - & + & + & । & 10 \\
\hline \multicolumn{15}{|l|}{ 5.4.1. Quercetalia cerridis } \\
\hline \multicolumn{15}{|l|}{ 5.4.1.1. Aceri tatarici-Quercion } \\
\hline Acer tataricum (Qpp) & $A 2$ & + & - & - & - & - & - & - & - & - & - & + & 1 & 10 \\
\hline \multicolumn{15}{|l|}{ 1. Cypero-Phragmitea } \\
\hline \multicolumn{15}{|l|}{ 1.1. Phragmitetea } \\
\hline Eupatorium cannabinum (Epa, Sal, Ata, Ai) & C & - & - & - & + & + & + & + & + & - & - & + & III & 50 \\
\hline Carex acutiformis (Mag, Cgr, Moa, Sal, Ata) & C & & & & + & & & + & + & + & & + & II & 40 \\
\hline Solanum dulcamara (Cn, Bia, Spu) & C & & - & - & + & + & + & + & & - & - & + & ॥ & 40 \\
\hline Lycopus europaeus (Moa, Cn, Bia, Spu, Ata) & C & - & - & - & + & - & + & - & - & + & - & + & $\|$ & 30 \\
\hline Epilobium hirsutum (FiC, Cn, Bia) & $\mathrm{C}$ & - & - & - & - & + & - & - & - & - & - & + & I & 10 \\
\hline Epilobium tetragonum (Mag, Des, Bia) & $c$ & - & - & - & + & - & - & - & - & - & - & + & । & 10 \\
\hline Equisetum palustre (Moa, Moa, Spu, Ata, Ai) & C & - & - & - & - & - & + & - & - & - & - & + & । & 10 \\
\hline Galium palustre (Mag, Moa, FPi, Spu, Ata) & $c$ & - & - & - & - & - & - & - & - & + & - & + & । & 10 \\
\hline Myosotis nemorosa (Moa, Spu, Ata, Cn) & C & - & - & - & - & - & - & - & . & + & - & + & । & 10 \\
\hline \multicolumn{15}{|l|}{ 2. Molinio-Arrhenatherea } \\
\hline Poa trivialis (Pte, Spu, Ata, Ai) & C & - & - & + & + & - & - & + & - & + & + & + & III & 50 \\
\hline Lychnis flos-cuculi (Mag, Ata) & C & & - & - & - & + & - & - & + & - & - & + & I & 20 \\
\hline \multicolumn{15}{|l|}{ 2.1. Molinio-Juncetea } \\
\hline Deschampsia caespitosa (Des, Sal, Ata, Ai) & C & + & + & + & + & - & - & - & + & - & - & + & III & 50 \\
\hline Cirsium rivulare (Mag, Ata, Ai) & C & & & & + & & + & + & & & & + & $\|$ & 30 \\
\hline Cirsium canum (Mag, Ata, Ai) & C & - & & & + & - & + & - & & & & + & । & 20 \\
\hline Symphytum officinale (Pte, Cn, Spu, Ata, Ai) & C & - & - & - & - & - & - & - & - & + & - & + & । & 10 \\
\hline Veratrum album (Ata, Ai) & C & - & - & - & - & + & - & - & - & - & - & + & 1 & 10 \\
\hline \multicolumn{15}{|l|}{ 2.1.1. Molinietalia coeruleae } \\
\hline Angelica sylvestris (Mag, Ata, Ai) & c & - & - & - & + & + & + & + & 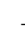 & - & - & + & $\|$ & 40 \\
\hline \multicolumn{15}{|l|}{ 2.1.1.1. Filipendulo-Cirsion oleracei } \\
\hline Filipendula ulmaria (Moa, Sal, Ata, Ai) & c & - & - & - & + & - & - & - & 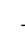 & - & - & + & 1 & 10 \\
\hline \multicolumn{15}{|l|}{ 2.2. Calluno-Ulicetea } \\
\hline \multicolumn{15}{|l|}{ 2.2.1. Vaccinio-Genistetalia } \\
\hline \multicolumn{15}{|l|}{ 2.2.1.1. Calluno-Genistion } \\
\hline \multirow[t]{3}{*}{ Betula pendula (Qr, APa) } & A1 & & & + & & & & & & & & + & 1 & 10 \\
\hline & A2 & - & + & - & - & - & - & - & . & - & - & + & I & 10 \\
\hline & $\mathrm{S}$ & - & + & + & - & - & - & - & - & - & - & + & 1 & 20 \\
\hline
\end{tabular}




\section{1. táblázat: Paridi quadrifoliae-Alnetum glutinosae, Nyírség folytatása}

\section{Festuco-Bromea} Szüntaxon/Faj

\begin{tabular}{l|llllllllll|llll} 
Szint & 1 & 2 & 3 & 4 & 5 & 6 & 7 & 8 & 9 & 10 & A-D & K & K\% \\
\hline
\end{tabular}

3.1. Festuco-Brometea

3.1.1. Festucetalia valesiacae 3.1.1.1. Festucion rupicolae Cynoglossum officinale (Onn) 4. Chenopodio-Scleranthea 4.1. Chenopodietea Arctium minus (Arc, Bia, Pla) Arctium lappa (Arc, Pla, Spu)

\subsection{Galio-Urticetea}

4.2.1. Calystegietalia sepium

\subsubsection{Galio-Alliarion}

Chaerophyllum temulum Alliaria petiolata (Epa)

\subsubsection{Calystegion sepium}

Myosoton aquaticum (Pte, Spu, Ata, Ai)

\subsection{Bidentetea}

\subsubsection{Bidentetalia}

Persicaria dubia (Alo, Bon, Spu, Ai)

4.4. Epilobietea angustifolii

\subsubsection{Epilobietalia}

Galeopsis bifida (Cn)

\section{Indifferens}

Lysimachia nummularia (Pte, Moa, Bia) Sambucus nigra (Epa, SaS, QFt)

Galium aparine (Sea, Epa, QFt)

Glechoma hederacea (MoA, QFt, Sal, Ai)

Rubus caesius (Spu)

Urtica dioica (Arc, GA, Epa, Spu)

Torilis japonica (Arc, GA, Epa, QFt)

Equisetum arvense (MoA, Sea, Sal, Ata, Ai)

Stellaria media (ChS, QFt, Spu)

Mentha aquatica (Pte, Moa, Spu, Ata, Ai)

Taraxacum officinale agg. (MoA, ChS)

Anthriscus cerefolium (Arc, GA)

Chelidonium majus (Che, Arc, GA, Epa)

Ranunculus repens (Pte, MoA, ChS, Spu, Ata)

7. Adventiva

Celtis occidentalis

Acer negundo

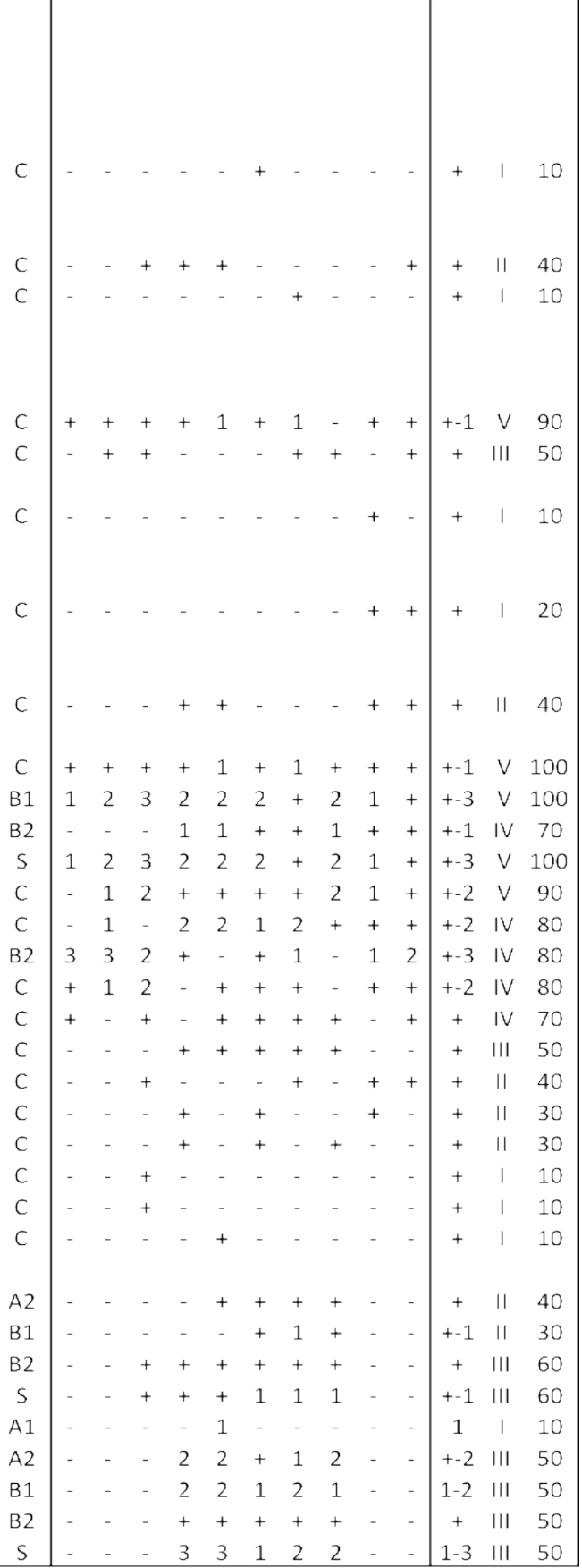


1. táblázat: Paridi quadrifoliae-Alnetum glutinosae, Nyírség folytatása

\begin{tabular}{|c|c|c|c|c|c|c|c|c|c|c|c|c|c|c|}
\hline Szüntaxon/Faj & Szint & 1 & 2 & 3 & 4 & 5 & 6 & 7 & 8 & 9 & 10 & A-D & $\mathrm{K}$ & $\mathrm{K} \%$ \\
\hline \multirow[t]{3}{*}{ Fraxinus pennsylvanica } & $A 2$ & - & + & + & - & - & - & - & - & - & - & + & 1 & 20 \\
\hline & B1 & + & + & + & - & - & - & - & + & - & - & + & ॥ & 40 \\
\hline & $S$ & + & + & + & - & - & - & - & + & - & - & + & ॥ & 40 \\
\hline \multirow[t]{4}{*}{ Juglans nigra } & $\mathrm{A} 1$ & - & - & + & - & - & - & - & - & - & - & + & । & 10 \\
\hline & $\mathrm{A} 2$ & - & - & + & - & - & - & - & - & - & - & + & I & 10 \\
\hline & $\mathrm{B} 2$ & - & - & + & - & - & - & - & - & - & - & + & 1 & 10 \\
\hline & $\mathrm{S}$ & - & - & 1 & - & - & - & - & - & - & - & 1 & I & 10 \\
\hline Morus alba & $B 2$ & - & - & + & - & - & - & - & - & - & - & + & । & 10 \\
\hline Populus $\times$ euramericana & $\mathrm{A} 1$ & - & - & - & - & - & - & - & 1 & - & - & 1 & I & 10 \\
\hline Quercus rubra & B2 & - & - & - & - & - & - & - & - & - & + & + & 1 & 10 \\
\hline Robinia pseudo-acacia & $\mathrm{B} 2$ & - & - & - & - & + & - & - & - & - & - & + & 1 & 10 \\
\hline
\end{tabular}




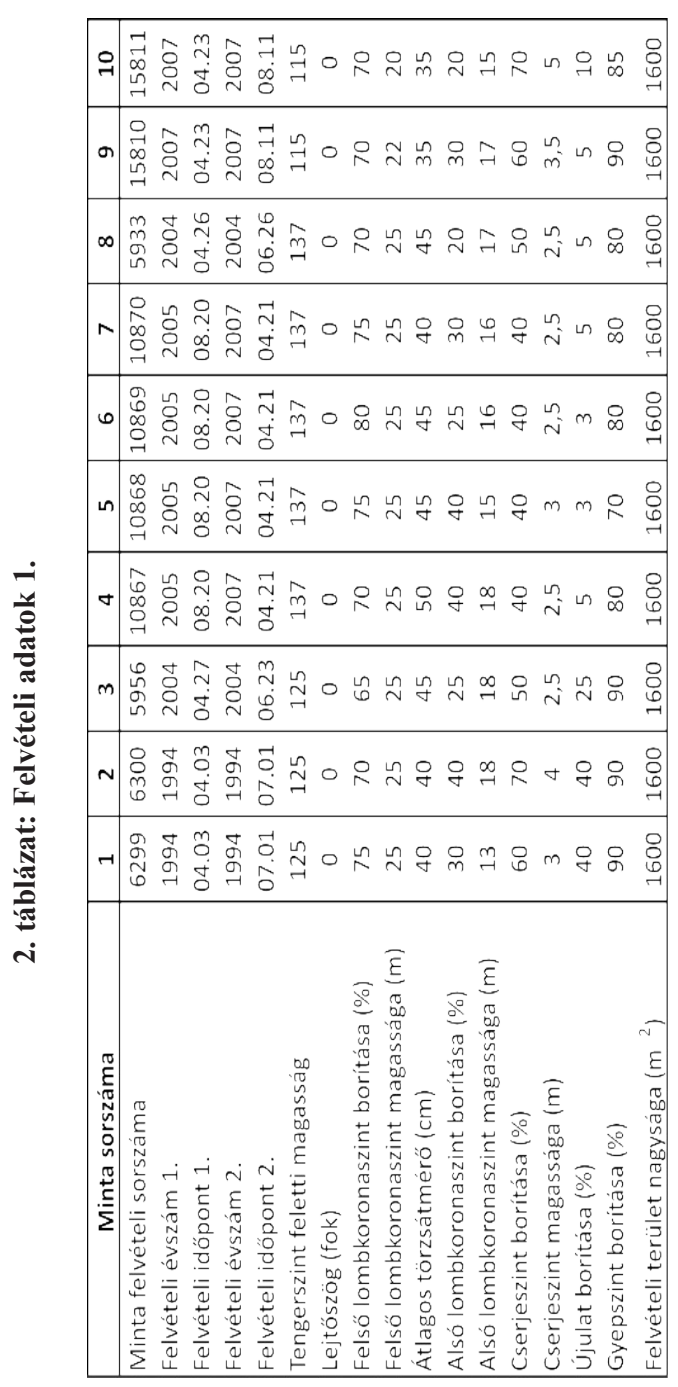




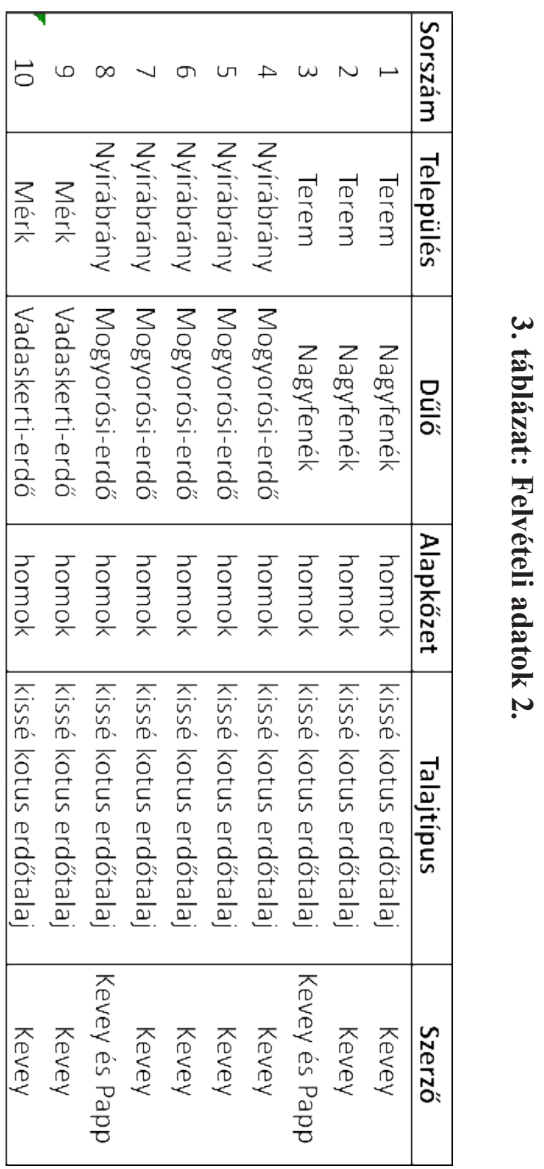


4. táblázat: Karakterfajok aránya

Nyírség: Paridi quadrifoliae-Alnetum glutinosae (Kevey és Papp ined.: 10 felv.),

Szigetköz: Paridi quadrifoliae-Alnetum glutinosae (Kevey 2008: 25 felv.)

Börzsöny: Aegopodio-Alnetum glutinosae (Nagy 1997: 15 felv.)

\begin{tabular}{|c|c|c|c|c|c|c|}
\hline \multirow[t]{2}{*}{ Szüntaxon } & \multicolumn{3}{|c|}{$\begin{array}{c}\text { Csoportrészesedés } \\
\text { Nyírség Szigetköz Börzsöny }\end{array}$} & \multicolumn{3}{|c|}{$\begin{array}{c}\text { Csoporttömeg } \\
\text { Nyírség Szigetköz Börzsöny } \\
\end{array}$} \\
\hline & 0,00 & 0,00 & 0,00 & 0,00 & 0,00 & 0,00 \\
\hline Salicetea purpureae & 0,00 & 0,00 & 0,00 & 0,00 & 0,00 & 0,00 \\
\hline Salicetalia purpureae & 1,72 & 2,25 & 1,60 & 2,21 & 3,23 & 0,53 \\
\hline Salicion albae & 2,43 & 4,24 & 1,72 & 1,66 & 4,92 & 4,01 \\
\hline Populenion nigro-albae & 0,41 & 0,17 & 0,57 & 0,04 & 0,02 & 0,09 \\
\hline Salicion albae s.l. & 2,84 & 4,41 & 2,29 & 1,70 & 4,94 & 4,10 \\
\hline Salicetalia purpureae s.I. & 4,56 & 6,66 & 3,89 & 3,91 & 8,17 & 4,63 \\
\hline Salicetea purpureae s.I. & 4,56 & 6,66 & 3,89 & 3,91 & 8,17 & 4,63 \\
\hline Alnetea glutinosae & 0,00 & 0,00 & 0,00 & 0,00 & 0,00 & 0,00 \\
\hline Alnetalia glutinosae & 4,57 & 3,58 & 2,01 & 14,20 & 5,08 & 7,91 \\
\hline Alnion glutinosae & 0,00 & 0,12 & 0,00 & 0,00 & 0,03 & 0,00 \\
\hline Alnetalia glutinosae s.I. & 4,57 & 3,70 & 2,01 & 14,20 & 5,11 & 7,91 \\
\hline Alnetea glutinosae s.I. & 4,57 & 3,70 & 2,01 & 14,20 & 5,11 & 7,91 \\
\hline Querco-Fagetea & 16,65 & 13,14 & 12,92 & 15,94 & 15,58 & 14,70 \\
\hline Fagetalia sylvaticae & 12,33 & 15,36 & 20,99 & 13,35 & 15,25 & 17,48 \\
\hline Alnion incanae & 8,74 & 9,91 & 8,29 & 17,17 & 16,07 & 14,94 \\
\hline Alnenion glutinosae-incanae & 0,65 & 0,88 & 2,16 & 7,18 & 5,70 & 12,17 \\
\hline Ulmenion & 1,19 & 1,01 & 0,12 & 1,18 & 0,81 & 0,13 \\
\hline Alnion incanae s.l. & 10,58 & 11,80 & 10,57 & 25,53 & 22,58 & 27,24 \\
\hline Fagion sylvaticae & 0,00 & 0,00 & 0,00 & 0,00 & 0,00 & 0,00 \\
\hline Eu-Fagenion & 0,00 & 0,00 & 0,98 & 0,00 & 0,00 & 0,72 \\
\hline Carpinenion betuli & 2,99 & 2,42 & 4,61 & 0,87 & 1,63 & 6,56 \\
\hline Tilio-Acerenion & 0,00 & 1,57 & 1,78 & 0,00 & 5,68 & 0,41 \\
\hline Fagion sylvaticae s.l. & 2,99 & 3,99 & 7,37 & 0,87 & 7,31 & 7,69 \\
\hline Aremonio-Fagion & 0,35 & 0,05 & 0,00 & 0,04 & 0,01 & 0,00 \\
\hline Fagetalia sylvaticae s.I. & 26,25 & 31,20 & 38,93 & 39,79 & 45,15 & 52,41 \\
\hline Quercetalia roboris & 0,74 & 0,23 & 0,93 & 0,10 & 0,03 & 0,41 \\
\hline Deschampsio flexuosae-Fagion & 0,00 & 0,00 & 0,08 & 0,00 & 0,00 & 0,01 \\
\hline Quercion robori-petraeae & 0,00 & 0,25 & 0,00 & 0,00 & 0,03 & 0,00 \\
\hline Genisto germanicae-Quercenion & 0,00 & 0,00 & 0,00 & 0,00 & 0,00 & 0,00 \\
\hline Castaneo-Quercenion & 0,00 & 0,00 & 0,00 & 0,00 & 0,00 & 0,00 \\
\hline Quercion robori-petraeae s.I. & 0,00 & 0,25 & 0,00 & 0,00 & 0,03 & 0,00 \\
\hline Quercetalia roboris s.I. & 0,74 & 0,48 & 1,01 & 0,10 & 0,06 & 0,42 \\
\hline Querco-Fagetea s.I. & 43,64 & 44,82 & 52,86 & 55,83 & 60,79 & 67,53 \\
\hline Quercetea pubescentis-petraeae & 12,47 & 10,42 & 7,66 & 7,39 & 12,38 & 8,18 \\
\hline Orno-Cotinetalia & 0,00 & 0,00 & 0,00 & 0,00 & 0,00 & 0,00 \\
\hline Orno-Cotinion & 0,00 & 0,07 & 0,00 & 0,00 & 0,01 & 0,00 \\
\hline Orno-Cotinetalia s.I. & 0,00 & 0,07 & 0,00 & 0,00 & 0,01 & 0,00 \\
\hline Quercetalia cerridis & 0,09 & 0,07 & 0,06 & 0,03 & 0,01 & 0,26 \\
\hline Quercion farnetto & 0,35 & 0,00 & 0,00 & 0,04 & 0,00 & 0,00 \\
\hline Aceri tatarici-Quercion & 0,26 & 0,39 & 0,08 & 0,24 & 1,13 & 0,04 \\
\hline Quercetalia cerridis s.I. & 0,70 & 0,46 & 0,14 & 0,31 & 1,14 & 0,30 \\
\hline Prunetalia spinosae & 0,67 & 0,42 & 0,43 & 0,07 & 0,05 & 0,06 \\
\hline Berberidion & 0,09 & 0,01 & 0,06 & 0,03 & 0,00 & 0,26 \\
\hline Prunion fruticosae & 0,23 & 0,12 & 0,36 & 0,02 & 0,01 & 0,05 \\
\hline Prunetalia spinosae s.l. & 0,99 & 0,55 & 0,85 & 0,12 & 0,06 & 0,37 \\
\hline Quercetea pubescentis-petraeae s.I. & 14,16 & 11,50 & 8,65 & 7,82 & 13,59 & 8,85 \\
\hline Querco-Fagea s.I. & 66,93 & 66,68 & 67,41 & 81,76 & 87,66 & 88,92 \\
\hline Abieti-Piceea & 0,12 & 0,01 & 0,00 & 0,01 & 0,00 & 0,00 \\
\hline
\end{tabular}


4. táblázat: Karakterfajok aránya folytatása

\begin{tabular}{|c|c|c|c|c|c|c|}
\hline \multirow{2}{*}{\begin{tabular}{|l} 
Szüntaxon \\
Vaccinio-Piceetea
\end{tabular}} & \multicolumn{3}{|c|}{$\begin{array}{c}\text { Csoportrészesedés } \\
\text { Nyírség Szigetköz Börzsöny }\end{array}$} & \multicolumn{3}{|c|}{$\begin{array}{c}\text { Csoporttömeg } \\
\text { Nyírség Szigetköz Börzsöny }\end{array}$} \\
\hline & 0,06 & 0,00 & 0,69 & 0,01 & 0,00 & 0,58 \\
\hline Pino-Quercetalia & 0,00 & 0,00 & 0,00 & 0,00 & 0,00 & 0,00 \\
\hline Pino-Quercion & 0,44 & 0,25 & 0,35 & 0,05 & 0,03 & 0,07 \\
\hline Pino-Quercetalia s.I. & 0,44 & 0,25 & 0,35 & 0,05 & 0,03 & 0,07 \\
\hline Vaccinio-Piceetea s.l. & 0,50 & 0,25 & 1,04 & 0,06 & 0,03 & 0,65 \\
\hline Abieti-Piceea s.l. & 0,62 & 0,26 & 1,04 & 0,07 & 0,03 & 0,65 \\
\hline Lemno-Potamea & 0,00 & 0,00 & 0,00 & 0,00 & 0,00 & 0,00 \\
\hline Potametea & 0,00 & 0,01 & 0,00 & 0,00 & 0,00 & 0,00 \\
\hline Potametalia & 0,00 & 0,01 & 0,08 & 0,00 & 0,00 & 0,01 \\
\hline Potametea s.I. & 0,00 & 0,02 & 0,08 & 0,00 & 0,00 & 0,01 \\
\hline Lemno-Potamea s.I. & 0,00 & 0,02 & 0,08 & 0,00 & 0,00 & 0,01 \\
\hline Cypero-Phragmitea & 0,00 & 0,00 & 0,00 & 0,00 & 0,00 & 0,00 \\
\hline Phragmitetea & 1,52 & 3,35 & 2,60 & 0,21 & 0,57 & 0,50 \\
\hline Phragmitetalia & 0,00 & 0,00 & 0,00 & 0,00 & 0,00 & 0,00 \\
\hline Phragmition & 0,00 & 0,05 & 0,00 & 0,00 & 0,01 & 0,00 \\
\hline Phragmitetalia s.I. & 0,00 & 0,05 & 0,00 & 0,00 & 0,01 & 0,00 \\
\hline Nasturtio-Glycerietalia & 0,00 & 0,00 & 0,00 & 0,00 & 0,00 & 0,00 \\
\hline Glycerio-Sparganion & 0,00 & 0,06 & 0,87 & 0,00 & 0,01 & 0,13 \\
\hline Nasturtio-Glycerietalia s.I. & 0,00 & 0,06 & 0,87 & 0,00 & 0,01 & 0,13 \\
\hline Magnocaricetalia & 0,00 & 0,00 & 0,00 & 0,00 & 0,00 & 0,00 \\
\hline Magnocaricion & 0,70 & 0,85 & 0,21 & 0,07 & 0,22 & 0,05 \\
\hline Caricenion rostratae & 0,00 & 0,02 & 0,00 & 0,00 & 0,00 & 0,00 \\
\hline Caricenion gracilis & 0,12 & 0,34 & 0,10 & 0,01 & 0,16 & 0,04 \\
\hline Magnocaricion s.I. & 0,82 & 1,21 & 0,31 & 0,08 & 0,38 & 0,09 \\
\hline Magnocaricetalia s.I. & 0,82 & 1,21 & 0,31 & 0,08 & 0,38 & 0,09 \\
\hline Phragmitetea s.l. & 2,34 & 4,67 & 3,78 & 0,29 & 0,97 & 0,72 \\
\hline Isoëto-Nanojuncetea & 0,00 & 0,00 & 0,00 & 0,00 & 0,00 & 0,00 \\
\hline Nanocyperetalia & 0,00 & 0,00 & 0,00 & 0,00 & 0,00 & 0,00 \\
\hline Nanocyperion flavescentis & 0,00 & 0,09 & 0,30 & 0,00 & 0,01 & 0,06 \\
\hline Nanocyperetalia s.l. & 0,00 & 0,09 & 0,30 & 0,00 & 0,01 & 0,06 \\
\hline Isoëto-Nanojuncetea s.I. & 0,00 & 0,09 & 0,30 & 0,00 & 0,01 & 0,06 \\
\hline Montio-Cardaminetea & 0,00 & 0,00 & 0,00 & 0,00 & 0,00 & 0,00 \\
\hline Montio-Cardaminetalia & 0,00 & 0,00 & 0,17 & 0,00 & 0,00 & 0,03 \\
\hline Cardamini-Montion & 0,00 & 0,00 & 0,06 & 0,00 & 0,00 & 0,03 \\
\hline Montio-Cardaminetalia s.I. & 0,00 & 0,00 & 0,23 & 0,00 & 0,00 & 0,06 \\
\hline Montio-Cardaminetea s.I. & 0,00 & 0,00 & 0,23 & 0,00 & 0,00 & 0,06 \\
\hline Cypero-Phragmitea s.I. & 2,34 & 4,76 & 4,31 & 0,29 & 0,98 & 0,84 \\
\hline Oxycocco-Caricea nigrae & 0,00 & 0,00 & 0,00 & 0,00 & 0,00 & 0,00 \\
\hline Scheuchzerio-Caricetea nigrae & 0,00 & 0,00 & 0,00 & 0,00 & 0,00 & 0,00 \\
\hline Scheuchzerio-Caricetalia nigrae & 0,00 & 0,17 & 0,19 & 0,00 & 0,03 & 0,03 \\
\hline Scheuchzerio-Caricetea nigrae s.l. & 0,00 & 0,17 & 0,19 & 0,00 & 0,03 & 0,03 \\
\hline Oxycocco-Caricea nigrae s.l. & 0,00 & 0,17 & 0,19 & 0,00 & 0,03 & 0,03 \\
\hline Molinio-Arrhenatherea & 1,90 & 0,86 & 1,30 & 0,66 & 0,16 & 0,23 \\
\hline Molinio-Juncetea & 1,12 & 1,32 & 0,72 & 0,17 & 0,29 & 0,15 \\
\hline Molinietalia coeruleae & 0,41 & 0,88 & 0,59 & 0,04 & 0,23 & 0,16 \\
\hline Deschampsion caespitosae & 0,22 & 0,96 & 0,03 & 0,02 & 0,20 & 0,00 \\
\hline Filipendulo-Cirsion oleracei & 0,08 & 0,16 & 0,51 & 0,01 & 0,07 & 0,15 \\
\hline Alopecurion pratensis & 0,07 & 0,05 & 0,03 & 0,01 & 0,01 & 0,01 \\
\hline Molinietalia coeruleae s.I. & 0,78 & 2,05 & 1,16 & 0,08 & 0,51 & 0,32 \\
\hline Molinio-Juncetea s.I. & 1,90 & 3,37 & 1,88 & 0,25 & 0,80 & 0,47 \\
\hline
\end{tabular}


4. táblázat: Karakterfajok aránya folytatása

\begin{tabular}{|c|c|c|c|c|c|c|}
\hline \multirow{2}{*}{$\begin{array}{l}\text { Szüntaxon } \\
\text { Arrhenatheretea }\end{array}$} & \multicolumn{3}{|c|}{$\begin{array}{c}\text { Csoportrészesedés } \\
\text { Nyírség Szigetköz Börzsöny }\end{array}$} & \multicolumn{3}{|c|}{\begin{tabular}{|c|} 
Csoporttömeg \\
Nyírség Szigetköz Börzsöny \\
\end{tabular}} \\
\hline & 0,00 & 0,00 & 0,00 & 0,00 & 0,00 & 0,00 \\
\hline Arrhenatheretalia & 0,06 & 0,28 & 0,18 & 0,01 & 0,03 & 0,03 \\
\hline Arrhenatherion elatioris & 0,00 & 0,03 & 0,04 & 0,00 & 0,00 & 0,01 \\
\hline Arrhenatheretalia s.I. & 0,06 & 0,31 & 0,22 & 0,01 & 0,03 & 0,04 \\
\hline Arrhenatheretea s.l. & 0,06 & 0,31 & 0,22 & 0,01 & 0,03 & 0,04 \\
\hline Nardo-Callunetea & 0,00 & 0,00 & 0,00 & 0,00 & 0,00 & 0,00 \\
\hline Nardetalia & 0,00 & 0,00 & 0,00 & 0,00 & 0,00 & 0,00 \\
\hline Nardo-Agrostion tenuis & 0,03 & 0,05 & 0,00 & 0,00 & 0,01 & 0,00 \\
\hline Nardetalia s.I. & 0,03 & 0,05 & 0,00 & 0,00 & 0,01 & 0,00 \\
\hline Nardo-Callunetea s.I. & 0,03 & 0,05 & 0,00 & 0,00 & 0,01 & 0,00 \\
\hline Calluno-Ulicetea & 0,00 & 0,00 & 0,00 & 0,00 & 0,00 & 0,00 \\
\hline Vaccinio-Genistetalia & 0,00 & 0,00 & 0,00 & 0,00 & 0,00 & 0,00 \\
\hline Calluno-Genistion & 0,12 & 0,01 & 0,00 & 0,01 & 0,00 & 0,00 \\
\hline Vaccinio-Genistetalia s.I. & 0,12 & 0,01 & 0,00 & 0,01 & 0,00 & 0,00 \\
\hline Calluno-Ulicetea s.I. & 0,12 & 0,01 & 0,00 & 0,01 & 0,00 & 0,00 \\
\hline Molinio-Arrhenatherea s.I. & 4,01 & 4,60 & 3,40 & 0,93 & 1,00 & 0,74 \\
\hline Puccinellio-Salicornea & 0,00 & 0,00 & 0,00 & 0,00 & 0,00 & 0,00 \\
\hline Festuco-Puccinellietea & 0,00 & 0,16 & 0,00 & 0,00 & 0,02 & 0,00 \\
\hline Festuco-Puccinellietalia & 0,03 & 0,12 & 0,04 & 0,00 & 0,01 & 0,01 \\
\hline Puccinellion limosae & 0,00 & 0,00 & 0,00 & 0,00 & 0,00 & 0,00 \\
\hline Puccinellion peisonis & 0,00 & 0,00 & 0,00 & 0,00 & 0,00 & 0,00 \\
\hline Juncion gerardi & 0,00 & 0,00 & 0,00 & 0,00 & 0,00 & 0,00 \\
\hline Beckmannion eruciformis & 0,00 & 0,00 & 0,00 & 0,00 & 0,00 & 0,00 \\
\hline Festuco-Puccinellietalia s.I. & 0,03 & 0,12 & 0,04 & 0,00 & 0,01 & 0,01 \\
\hline Festuco-Puccinellietea s.l. & 0,03 & 0,28 & 0,04 & 0,00 & 0,03 & 0,01 \\
\hline Puccinellio-Salicornea s.I. & 0,03 & 0,28 & 0,04 & 0,00 & 0,03 & 0,01 \\
\hline Festuco-Bromea & 0,00 & 0,00 & 0,00 & 0,00 & 0,00 & 0,00 \\
\hline Festucetea vaginatae & 0,00 & 0,00 & 0,00 & 0,00 & 0,00 & 0,00 \\
\hline Festucetalia vaginatae & 0,00 & 0,00 & 0,00 & 0,00 & 0,00 & 0,00 \\
\hline Festucion vaginatae & 0,00 & 0,01 & 0,00 & 0,00 & 0,00 & 0,00 \\
\hline Festucetalia vaginatae s.I. & 0,00 & 0,01 & 0,00 & 0,00 & 0,00 & 0,00 \\
\hline Festucetea vaginatae s.l. & 0,00 & 0,01 & 0,00 & 0,00 & 0,00 & 0,00 \\
\hline Festuco-Brometea & 0,06 & 0,09 & 0,15 & 0,01 & 0,01 & 0,02 \\
\hline Festucetalia valesiacae & 0,00 & 0,00 & 0,00 & 0,00 & 0,00 & 0,00 \\
\hline Asplenio-Festucion pallentis & 0,00 & 0,00 & 0,04 & 0,00 & 0,00 & 0,01 \\
\hline Festucion rupicolae & 0,09 & 0,04 & 0,04 & 0,01 & 0,00 & 0,01 \\
\hline Festucetalia valesiacae s.I. & 0,09 & 0,04 & 0,08 & 0,01 & 0,00 & 0,02 \\
\hline Festuco-Brometea s.I. & 0,15 & 0,13 & 0,23 & 0,02 & 0,01 & 0,04 \\
\hline Festuco-Bromea s.I. & 0,15 & 0,14 & 0,23 & 0,02 & 0,01 & 0,04 \\
\hline Chenopodio-Scleranthea & 0,38 & 0,19 & 0,44 & 0,04 & 0,02 & 0,10 \\
\hline Secalietea & 0,54 & 0,67 & 0,58 & 0,38 & 0,15 & 0,15 \\
\hline Secalietalia & 0,00 & 0,00 & 0,00 & 0,00 & 0,00 & 0,00 \\
\hline Caucalidion platycarpos & 0,00 & 0,01 & 0,00 & 0,00 & 0,00 & 0,00 \\
\hline Secalietalia s.I. & 0,00 & 0,01 & 0,00 & 0,00 & 0,00 & 0,00 \\
\hline Secalietea s.I. & 0,54 & 0,68 & 0,58 & 0,38 & 0,15 & 0,15 \\
\hline Chenopodietea & 0,25 & 0,42 & 0,48 & 0,03 & 0,08 & 0,07 \\
\hline Onopordetalia & 0,00 & 0,00 & 0,00 & 0,00 & 0,00 & 0,00 \\
\hline Onopordion acanthii & 0,09 & 0,00 & 0,00 & 0,01 & 0,00 & 0,00 \\
\hline Onopordetalia s.I. & 0,09 & 0,00 & 0,00 & 0,01 & 0,00 & 0,00 \\
\hline
\end{tabular}


4. táblázat: Karakterfajok aránya folytatása

\begin{tabular}{|c|c|c|c|c|c|c|}
\hline Szüntaxon & \multicolumn{3}{|c|}{$\begin{array}{c}\text { Csoportrészesedés } \\
\text { Nyírség Szigetköz Börzsöny }\end{array}$} & \multicolumn{3}{|c|}{$\begin{array}{c}\text { Csoporttömeg } \\
\text { Nyírség Szigetköz Börzsöny }\end{array}$} \\
\hline Chenopodietea s.l. & 0,34 & 0,42 & 0,48 & 0,04 & 0,08 & 0,07 \\
\hline Artemisietea & 0,00 & 0,00 & 0,00 & 0,00 & 0,00 & 0,00 \\
\hline Artemisietalia & 0,00 & 0,00 & 0,00 & 0,00 & 0,00 & 0,00 \\
\hline Arction lappae & 0,83 & 0,53 & 0,52 & 0,22 & 0,12 & 0,20 \\
\hline Artemisietalia s.l. & 0,83 & 0,53 & 0,52 & 0,22 & 0,12 & 0,20 \\
\hline Artemisietea s.l. & 0,83 & 0,53 & 0,52 & 0,22 & 0,12 & 0,20 \\
\hline Galio-Urticetea & 0,00 & 0,00 & 0,00 & 0,00 & 0,00 & 0,00 \\
\hline Calystegietalia sepium & 0,00 & 0,00 & 0,00 & 0,00 & 0,00 & 0,00 \\
\hline Galio-Alliarion & 3,57 & 1,20 & 1,82 & 0,70 & 0,49 & 0,40 \\
\hline Calystegion sepium & 2,34 & 2,85 & 2,63 & 0,25 & 1,11 & 2,29 \\
\hline Calystegietalia sepium s.l. & 5,91 & 4,05 & 4,45 & 0,95 & 1,60 & 2,69 \\
\hline Galio-Urticetea s.I. & 5,91 & 4,05 & 4,45 & 0,95 & 1,60 & 2,69 \\
\hline Bidentetea & 0,00 & 0,00 & 0,00 & 0,00 & 0,00 & 0,00 \\
\hline Bidentetalia & 1,03 & 1,03 & 1,40 & 0,16 & 0,16 & 0,27 \\
\hline Bidention tripartiti & 0,07 & 0,11 & 0,23 & 0,01 & 0,02 & 0,04 \\
\hline Bidentetalia s.I. & 1,10 & 1,14 & 1,63 & 0,17 & 0,18 & 0,31 \\
\hline Bidentetea s.I. & 1,10 & 1,14 & 1,63 & 0,17 & 0,18 & 0,31 \\
\hline Plantaginetea & 0,00 & 0,00 & 0,00 & 0,00 & 0,00 & 0,00 \\
\hline Plantaginetalia majoris & 0,22 & 0,44 & 0,08 & 0,02 & 0,09 & 0,01 \\
\hline Agropyro-Rumicion crispi & 0,00 & 0,01 & 0,00 & 0,00 & 0,00 & 0,00 \\
\hline Plantaginetalia majoris s.I. & 0,22 & 0,45 & 0,08 & 0,02 & 0,09 & 0,01 \\
\hline Plantaginetea s.I. & 0,22 & 0,45 & 0,08 & 0,02 & 0,09 & 0,01 \\
\hline Epilobietea angustifolii & 0,00 & 0,00 & 0,00 & 0,00 & 0,00 & 0,00 \\
\hline Epilobietalia & 6,45 & 3,56 & 5,57 & 4,05 & 1,28 & 2,14 \\
\hline Epilobion angustifolii & 0,06 & 0,07 & 0,39 & 0,04 & 0,01 & 0,06 \\
\hline Atropion bella-donnae & 0,00 & 0,00 & 0,08 & 0,00 & 0,00 & 0,01 \\
\hline Epilobietalia s.l. & 6,51 & 3,63 & 6,04 & 4,09 & 1,29 & 2,21 \\
\hline Epilobietea angustifolii s.I. & 6,51 & 3,63 & 6,04 & 4,09 & 1,29 & 2,21 \\
\hline Urtico-Sambucetea & 0,00 & 0,00 & 0,00 & 0,00 & 0,00 & 0,00 \\
\hline Sambucetalia & 0,00 & 0,00 & 0,00 & 0,00 & 0,00 & 0,00 \\
\hline Sambuco-Salicion capreae & 0,43 & 0,34 & 0,90 & 1,12 & 0,54 & 0,66 \\
\hline Sambucetalia s.I. & 0,43 & 0,34 & 0,90 & 1,12 & 0,54 & 0,66 \\
\hline Urtico-Sambucetea s.I. & 0,43 & 0,34 & 0,90 & 1,12 & 0,54 & 0,66 \\
\hline Chenopodio-Scleranthea s.I. & 16,26 & 11,43 & 15,12 & 7,03 & 4,07 & 6,40 \\
\hline Indifferens & 3,46 & 2,63 & 2,93 & 4,32 & 3,25 & 1,21 \\
\hline Adventiva & 3,48 & 4,26 & 0,50 & 4,79 & 2,00 & 0,14 \\
\hline
\end{tabular}

Nyírség: Paridi quadrifoliae-Alnetum glutinosae (Kevey és Papp ined.: 10 felv.) Szigetköz: Paridi quadrifoliae-Alnetum glutinosae (Kevey 2008: 25 felv.)

Börzsöny: Aegopodio-Alnetum glutinosae (Nagy 1997: 15 felv.) 


\section{5. táblázat: Differenciális fajok}

\begin{tabular}{|l|c|c|}
\hline & PA & FrU \\
\hline Konstans fajok & & \\
Alnus glutinosa & V & I \\
Lysimachia nummularia & V & II \\
Milium effusum & V & II \\
Cornus sanguinea & V & III \\
Fraxinus angustifolia & V & III \\
Arctium minus & II & V \\
Elymus caninus & II & V \\
Veronica sublobata & III & V \\
Szubkonstans fajok & & \\
Aegopodium podagraria & IV & I \\
Heracleum sphondylium & IV & I \\
Glechoma hederacea & IV & II \\
Humulus lupulus & IV & II \\
Convallaria majalis & II & IV \\
Galeopsis pubescens & II & IV \\
Akcesszórikus fajok & & \\
Ajuga reptans & III & - \\
Campanula trachelium & III & I \\
Deschampsia caespitosa & III & I \\
Eupatorium cannabinum & III & I \\
Frangula alnus & III & I \\
Listera ovata & III & I \\
Poa trivialis & III & I \\
Pulmonaria officinalis & III & I \\
Viola mirabilis & III & I \\
\hline
\end{tabular}

\begin{tabular}{|l|c|c|}
\hline & PA & FrU \\
\hline Viola reichenbachiana & III & I \\
Gagea pratensis & - & III \\
Ornithogalum boucheanum & - & III \\
Pyrus pyraster & - & III \\
Salvia glutinosa & - & III \\
Carex divulsa & I & III \\
Cerasus avium & I & III \\
Chelidonium majus & I & III \\
Szubakcesszórikus fajok & & \\
Allium ursinum & II & - \\
Cirsium rivulare & II & - \\
Lycopus europaeus & II & - \\
Mentha aquatica & II & - \\
Solanum dulcamara & II & - \\
Taraxacum officinale agg. & II & - \\
Acer platanoides & - & II \\
Anthriscus sylvestris & - & II \\
Arum orientale & - & II \\
Glechoma hirsuta & - & II \\
Impatiens parviflora & - & II \\
Lactuca quercina ssp. sagittata & - & II \\
Ornithogalum umbellatum & - & II \\
Padus serotina & - & II \\
Primula veris & - & II \\
Scilla vindobonensis & - & II \\
\hline Differenciális fajok száma & $\mathbf{2 5}$ & $\mathbf{2 2}$ \\
\hline
\end{tabular}

PA: Paridi quadrifoliae-Alnetum glutinosae, Nyírség (Kevey és Papp ined.: 10 felv.) FrU: Fraxino pannonicae-Ulmetum, Nyírség (Kevey et al. 2017: 25 felv.) 


\section{Irodalom}

Becking, R. W. 1957: The Zürich-Montpellier School of phytosociology. - Botanical Review 23: 411-488.

Borhidi, A. 1993: A magyar flóra szociális magatartás típusai, természetességi és relatív ökológiai értékszámai. - Janus Pannonius Tudományegyetem, Pécs, pp. 95.

Borhidi, A. 1995: Social behaviour types, the naturalness and relative ecological indicator values of the higher plants in the hungarian flora. - Acta Botanica Academiae Scientiarum Hungaricae 39: 97-81.

Borhidi, A., Kevey, B. 1996: An annotated checklist of the Hungarian plant communities II. - In: BorHIDI A. red.). Critical revision of the Hungarian plant comuunities. - Janus Pannonius University, Pécs, pp. 95-138.

Borhidi, A., Kevey, B., LendvaI, G. 2012: Plant communities of Hungary. - Akadémiai Kiadó, Budapest, pp. 544.

Braun-Blanquet, J. 1964: Pflanzensoziologie (ed. 3.). - Springer Verlag, Wien-New York, pp. 865.

Horváth, F., Dobolyi, Z. K., MorschHauser, T., LőKös, L., Karas, L., Szerdahelyi, T. 1995: Flóra adatbázis 1.2. - Vácrátót, pp. 267.

JAKUCS, P. 1967: Gedanken zur höheren Systematik der europäischen Laubwälder. - Contribuţii Botanice Cluj 1967: 159-166.

KEvey, B. 2008: Magyarország erdőtársulásai (Forest associations of Hungary). - Die Wälder von Ungarn Tilia 14: 1-488. + CD-adatbázis (230 táblázat + 244 ábra).

Kevey B., Papp L., LendvaI G. 2017: A Nyírség tölgy-kőris-szil ligetei (Fraxino pannonicae-Ulmetum Soó in Aszód 1935 corr. Soó 1963). - Kitaibelia 22(1): 179-220.

Kevey, B., HirmanN, A. 2002: „NS” számítógépes cönológiai programcsomag. - In: Aktuális flóra- és vegetációkutatások a Kárpát-medencében V. Pécs, 2002. március 8-10. (Összefoglalók), pp.: 74.

KIRÁLY, G. (szerk.) 2009: Új magyar füvészkönyv. Magyarország hajtásos növényei. Határozókulcsok. Aggteleki Nemzeti Park Igazgatóság, Jósvafő, pp. 616.

Mucina, L., Grabherr, G., WallnöFer, S. 1993: Die Pflanzengesellschaften Österreichs III. Wälder und Gebüsche. - Gustav Fischer, Jena - Stuttgart - New York, pp. 353.

NAGY, J. 1997: A Központi-Börzsöny gyertyános égerligetei. - Kitaibelia 2(2): 290-297.

Oberdorfer, E. 1953: Der europäische Auenwald. - Beiträge zur Naturkundlichen Forschung in Südwestdeutschland 12(1): 23-70.

Oberdorfer, E. 1992: Süddeutsche Pflanzengesellschaften IV. A. Textband. - Gustav Fischer Verlag, Jena Stuttgart - New York, pp. 282.

PawŁowski, B., SokoŁowski, M., Wallisch, K. 1928: Die Pflanzenassoziationen des Tatra-Gebirges VII. Die Pflanzenassoziationen und die Flora des Morskie Oko-Tales. - Bulletin International de l'Academie Polonaise des Sciences et des Lettres, Classe des Sciences Mathématiques et Naturelles; Série B: Sciences Naturelles, Cracovie, Suppl. 1927: 205-272.

Podani, J. 2001: SYN-TAX 2000 Computer Programs for Data Analysis in Ecologi and Systematics. Scientia, Budapest, pp. 53.

ŠomŠÁK, L. 1961: Jelšové porasty Spišško-gemerského Rudohoria. - Acta Facultatis Rerum Naturalium Universitatis Comenianae, Botanica 6(8-10): 407-449.

Soó, R. 1964, 1966, 1968, 1970, 1973, 1980: A magyar flóra és vegetáció rendszertani-növényföldrajzi kézikönyve I-VI. - Akadémiai Kiadó, Budapest.

Vlieger, J. 1937: Aperçu sur les unités phytosociologiques supérieures des Pays-Bas. - Nederlandsch Kruidkundig Archief 47: 335. 